\title{
Impacts of Fertilization Optimization on Ammonia Volatilization, Soil Nitrification, Denitration Intensity From Wheat Fields and Nitrogen Utilization Under Water-saving Irrigation
}

Zhen Zhang

Shandong Agricultural University

Zhenwen Yu

Shandong Agricultural University

Yongli Zhang ( $\nabla$ zhangylsdau@sohu.com )

Shandong Agricultural University

Yu Shi

Shandong Agricultural University

Research Article

Keywords: wheat, split nitrogen fertilization ammonia volatilization, nitrification intensity, denitration intensity

Posted Date: December 1st, 2021

DOI: https://doi.org/10.21203/rs.3.rs-1088606/v1

License: () (1) This work is licensed under a Creative Commons Attribution 4.0 International License. Read Full License 


\section{Abstract}

Scholars have proposed the practice of split $\mathrm{N}$ fertilizer application (SNFA), which has proven to be an effective approach for enhancing $\mathrm{N}$ use efficiency. However, the effect of SNFA on $\mathrm{NH}_{3}$ volatilization, nitrification and denitration in soil, remain largely unknown. As such, the current study assessed soil $\mathrm{NH}_{3}$ volatilization, nitrification and denitrification intensities, abundance of nitrogen cycle-related funetional genes, and invertase activity for different treatments. We applied a rate of $240 \mathrm{~kg} \cdot \mathrm{ha}^{-1}$ of $\mathrm{N}$, and the following fertilizer ratios of the percent base to that of topdressing under water-saving irrigation: N1 (basal/dressing, 100\%/0\%), N2 (basal/dressing, 70\%/30\%), N3 (basal/dressing, 50\%/50\%), N4 (basal/dressing, $30 \% / 70 \%$ ), and N5 (basal/dressing, $0 \% / 100 \%$ ). N3 treatment resulted in a significant decrease in rate of $\mathrm{NH}_{3}$ volatilization. This treatment also significantly reduced nitrification and denitrification intensities, primarily owing to the reduced functional genes abundance involved in the nitrogen cycle (Amoa-AOB, nirK and nirS) and reduced invertase activity (urease, nitrate reductase, nitrite reductase) in wheat-land soil. ${ }^{15} \mathrm{~N}$ tracer studies further demonstrated that N3 treatments significantly increased the grain nitrogen accumulation by $9.50-28.27 \%$ compared with that under other treatments. This increase was primarily due to an increase in the amount of $\mathrm{N}$ absorbed by wheat from soil and fertilizers, which was caused by an enhancement in total $\mathrm{N}$ uptake (7.2-21.81\%). Collectively, these results suggest that the $\mathrm{N} 3$ treatment (basal/dressing, 50\%/50\%) improves $\mathrm{N}$ uptake by wheat, reduces the soil $\mathrm{NH}_{3}$ volatilization rate, and has the potential to reduce the amount of $\mathrm{N}_{2} \mathrm{O}$ generated by nitrification and denitrification.

\section{Introduction}

$\mathrm{NH}_{3}$ volatilization is the major pathway by which nitrogen is lost from wheat cultivation systems (Abdo, 2021). Moreover, the proportion of total nitrogen lost as $\mathrm{NH}_{3}$ from nitrogen fertilizers varies from 9 to $40 \%$ (Fu et al., 2020). One of the major anthropogenic sources of $\mathrm{NH}_{3}$ release into the atmosphere is agricultural fields, primarilay owing to nitrogen based fertilization and the associated management of this practice. Meanwhile, the primary air pollutants now include atmospheric $\mathrm{NH}_{3}$, which is rapidly deposited on the earth's surface within 4 to $5 \mathrm{~km}$ of its sources (Behera, 2013). It is, therefore, crucial to manage nitrogen fertilizers in a manner that minimizes its effects on the environment. The simultaneous measurement of $\mathrm{NH}_{3}$ emissions has the potential to provide valuable information on the processes responsible for their formation, as well as their contribution to both environmental and air pollution.

Soil denitrification and nitrification are vital processes in the global nitrogen cycle (Jetten, 2008; Harter et al., 2014), as well as in the generation of environmental pollution, and plant metaolism (Kuypers et al., 2018; Li et al.,2018). Previous research has shown that high rates of nitrification and denitrification can result in reduced efficiency of nitrogen use by crops and a corresponding increase in loss of nitrogen to the atmosphere (e.g., as nitrogen oxides) or leaching into surface or ground waters (e.g., as $\mathrm{NO}_{3}{ }^{-}$or $\mathrm{NO}_{2}{ }^{-}$) (He et al., 2018; Herrera et al., 2016; Yang et al., 2017). Ammonia $\left(\mathrm{NH}_{4}^{\square}\right)$ is oxidized to nitrate $\left(\mathrm{NO}_{3}{ }^{-}\right)$by nitrite $\left(\mathrm{NO}_{2}{ }^{-}\right)$during nitrification with nitrite as an intermediary step. These processes are catalyzed separately by nitrite oxidoreductase ( $\mathrm{nxr}$ ) and ammonia monooxygenase (amoA), respectively. Meanwhile, denitrification is a sequential reduction by which $\mathrm{NO}_{3}{ }^{-}$is reduced to $\mathrm{N}_{2} \mathrm{O}$ and/or dinitrogen gas $\left(\mathrm{N}_{2}\right)$ via $\mathrm{NO}_{2}{ }^{-}$and nitric oxide (NO), which are catalyzed by a series of enzymes that include coppercontaining nitrite reductase (nirK) and cytochrome cd1-containing nitrite reductase (nirS). Hence, the functional genes for these enzymes have been used as molecular markers to study the dynamics of communities of denitrifying and nitrifying bacteria in an array of environments that include field soils (Morales et al., 2010; Chon et al., 2011; Petersen et al., 2012; Francis et al., 2013; Levy-Booth et al., 2014). However, soil nitrification and denitrification are highly vulnerable to the environment in the external soil (Neal et al., 2017; Wang et al., 2018). In addition, the effects of nitrogen fertilization on these processes can be modulated by the physiochemical properties of soil, including inorganic nitrogen (Fraser et al., 2017) and $\mathrm{N}$ cycle gene abundance and the critical enzyme activity (Neal et al., 2017). Thus, knowledge of the effects of soil physicochemical factors on soil nitrification and denitrification is vital to promote the efficient utilization of $\mathrm{N}$ in agriculture through the application of various strategies, including the amendment of soils and rational fertilization.

Soil moisture is an important element that affects $\mathrm{NH}_{3}$ emissions and soil nitrification and denitrification. Our previous research proposed a watersaving irrigation technology (WCT), which is based on measuring soil moisture at the key stage of wheat growth (man et al., 2014). Compared with traditional quantitative irrigation, this technology not only reduces water use, but also improves wheat growth and yield. Meanwhile, other studies have shown that improving irrigation management practices may significantly reduce $\mathrm{NH}_{3}$ emissions in Southeastern Queensland, Australia (Scheer et al., 2012). However, few studies have sought to understand the effects of split nitrogen fertilizer method under WCT condition on nitrogen loss.

The most important crop used to model cultivation on the North China Plain (NCP) is winter wheat. In an attempt to obtain high yields of grain, excessive amounts of nitrogen $(\mathrm{N})$ fertilizer are often used. The rate applied annually can be as high as $325 \mathrm{~kg} \mathrm{~N}^{-1}$, which poses a problem as fertilization with nitrogen serves as the major source of reactive N (Sun et al., 2020). Although this nutrient is indispensable for wheat ecosystems, an inadvertent effect can include high $\mathrm{N}$ loss and low fertilizer efficiency. In fact, the efficiency of N use (NUE) in wheat crops commonly ranges from $30-$ $40 \%$ following fertilization (Wu et al., 2019). However, the excessive use of $\mathrm{N}$ fertilizer contributes to rapid losses of $\mathrm{N}$ through volatilization in the form of ammonia $\left(\mathrm{NH}_{3}\right)$, nitrification, denitrification and surface runoff (Peng et al., 2006). Although previous research examined the individual effects of nitrogen fertilizer management on wheat plant nitrogen use efficiency, $\mathrm{NH}_{3}$ emission flux, as well as the rates of nitrification and denitrification in different ecosystems (Chen et al., 2012; Kou et al., 2015; Qiu et al., 2018), few experiments have investigated their combined effects (Qiu et al., 2018). In this experiment, ${ }^{15} \mathrm{~N}$ isotope tracer technology was used to compare nitrogen uptake and utilization in different split nitrogen fertilizer treatment schemes. To explore the potential effects of split nitrogen fertilizer on $\mathrm{NH}_{3}$ emission flux and the rates of denitrification and nitrification, as well as the 
utilization to plant nitrogen, a field experiment was performed in a crop of winter wheat. The goals of this study were as follows (1) determine the primary changes in ammonia volatilization in soil amended with split nitrogen fertilizer (2) define the impact of these amendments on nitrification and denitration intensity, as well as the relative abundance of genes for the $\mathrm{N}$ cycle in wheat-land soil; (3) characterize the primary properties of soil chemicals for that influence soil nitrification and denitrification intensity, and the relative abundance of genes involved in the $\mathrm{N}$ cycle; (4) elucidate the manner by which changes in the $\mathrm{N}$ cycle and fertility of the soil affect the availability of mineral nitrogen to be taken up by wheat plants.

\section{Materials And Methods}

\subsection{Experimental site description}

The field experiments took place in Xiaomeng town, Jining City, Shandong Province, China, during the growing seasons of winter wheat from 2016 to 2017 and 2017 to 2018 (Figure 1). This site is situated in a typical warm continental climate. The average annual climate factors include an average annual temperature of $15^{\circ} \mathrm{C}$, average annual precipitation of $600 \mathrm{~mm}$. Summer maize-winter wheat is the major crop rotation regime in this region. According to the FAO classification, the wheat-land soil is loam. The composition was as follows in the layer of soil tillage (0-20 $\mathrm{cm})$ : concentration of organic matter, $14.20 \mathrm{~g} \cdot \mathrm{kg}^{-1}$; available phosphorus, $38.11 \mathrm{mg} \cdot \mathrm{kg}^{-1}$; available potassium, $129.44 \mathrm{mg} \cdot \mathrm{kg}^{-1}$; available nitrogen, $122.60 \mathrm{mg} \cdot \mathrm{kg}^{-1}$; $\mathrm{PH}, 7.6$ and total nitrogen, $1.13 \mathrm{~g} \cdot \mathrm{kg}^{-1}$. The data for the mean monthly precipitation are shown in Figure 2.

\subsection{Split nitrogen fertilizer treatment and water-saving irrigation}

The cultivar of winter wheat was 'Jimai 22', which was used in this study. The wheat was seeded on October 12th, October 24th and harvested on June 8th, June 7th in 2016-2017 and 2017-2018. And density was 1.8 million·ha ${ }^{-1}$.

The field experiment consisted of five different split nitrogen fertilizer applications at an application rate of $240 \mathrm{~kg} \cdot \mathrm{ha} \mathrm{a}^{-1}$ (basal/dressing, $100 \% / 0 \%$, $70 \% / 30 \%, 50 \% / 50 \%, 30 \% / 70 \%, 100 \% / 0 \%$; hereafter referred to as N1, N2, N3, N4 and N5, respectively) with a randomized plot design (Table 1). Each application was performed in triplicate, resulting in a total of 15 plots (plot area $20 \mathrm{~m}^{2}$ ). The rate of fertilizer application that was selected was 240 $\mathrm{kg} \cdot \mathrm{ha}{ }^{-1}$, as it is commonly used by the local farmers. Single superphosphate $\left(\mathrm{P}_{2} \mathrm{O}_{5} 12 \%\right)$ and potassium chloride $\left(\mathrm{K}_{2} \mathrm{O} 60 \%\right)$ were applied to provide $\mathrm{P}$ $\left(\mathrm{P}_{2} \mathrm{O}_{5} 150 \mathrm{~kg} \cdot \mathrm{ha} \mathrm{a}^{-1}\right)$ and $\mathrm{K}\left(112.5 \mathrm{~K}_{2} \mathrm{O} \mathrm{kg} \cdot \mathrm{ha}{ }^{-1}\right)$, respectively. The basal fertilizer was comprised of $\mathrm{P}$ and $\mathrm{K}$, while the nitrogen was applied in two split applications. All potash and phosphate fertilizers, as well as the basal nitrogen fertilizer were spread over the soil surface before the wheat was sown. A rotary cultivar was used to immediately mix the soil to a depth of $20 \mathrm{~cm}$. During the jointing stage, nitrogen fertilizer was applied to create furrows that were immediately covered.

The soil moisture was measured to manage this parameter based on a WCT. The relative water content in the $0 \sim 40 \mathrm{~cm}$ soil layer was supplemented to $70 \%$ at the jointing and anthesis. The amounts of irrigation was calculated using the method of Man (Man et al., 2014). All irrigation processes involved the use of a hose, and the amount of water used to irrigated each event was determined manually and recorded with a water meter. The detailed apply nitrogen fertilizer and irrigation regimes are shown in Table 1. The fields were managed according to the local practices of farming with standard applications of herbicides and pesticides.

Table 1

Agronomic managements under different split nitrogen fertilizer treatments.

\begin{tabular}{|c|c|c|c|c|}
\hline \multirow[t]{2}{*}{ Treatments } & \multicolumn{3}{|c|}{ Fertilizer regimes } & Irrigation regimes \\
\hline & Seeding & & Jointing & Anthesis stage \\
\hline N1 & $\begin{array}{l}240 \mathrm{~N} \\
\mathrm{~kg} \cdot \mathrm{ha}^{-1} \\
\text { as urea }\end{array}$ & \multirow[t]{5}{*}{$\begin{array}{l}150 \mathrm{P}_{2} \mathrm{O}_{5} \mathrm{~kg} \cdot \mathrm{ha}^{-1} \text { as superphosphate } \\
\text { and } 112.5 \mathrm{~K}_{2} \mathrm{O} \mathrm{kg} \cdot \mathrm{ha}^{-1} \text { as potassium } \\
\text { chloride }\end{array}$} & $\begin{array}{l}0 \mathrm{~N} \\
\mathrm{~kg} \cdot \mathrm{ha}^{-1} \\
\text { as urea }\end{array}$ & \multirow[t]{5}{*}{$\begin{array}{l}\text { Relative water content in } 0 \sim 40 \mathrm{~cm} \text { soil layer is supplemented } \\
\text { to } 70 \% \text { according to soil moisture content in } 0 \sim 40 \mathrm{~cm} \text { soil } \\
\text { layer. }\end{array}$} \\
\hline N2 & $\begin{array}{l}168 \mathrm{~N} \\
\mathrm{~kg} \cdot \mathrm{ha}^{-1} \\
\text { as urea }\end{array}$ & & $\begin{array}{l}72 \mathrm{~N} \\
\mathrm{~kg} \cdot \mathrm{ha}^{-1} \\
\text { as urea }\end{array}$ & \\
\hline N3 & $\begin{array}{l}120 \mathrm{~N} \\
\mathrm{~kg} \cdot \mathrm{ha}^{-1} \\
\text { as urea }\end{array}$ & & $\begin{array}{l}120 \mathrm{~N} \\
\mathrm{~kg} \cdot \mathrm{ha}^{-1} \\
\text { as urea }\end{array}$ & \\
\hline N4 & $\begin{array}{l}72 \mathrm{~N} \\
\mathrm{~kg} \cdot \mathrm{ha}^{-1} \\
\text { as urea }\end{array}$ & & $\begin{array}{l}168 \mathrm{~N} \\
\mathrm{~kg} \cdot \mathrm{ha}^{-1} \\
\text { as urea }\end{array}$ & \\
\hline N5 & $\begin{array}{l}0 \mathrm{~N} \\
\mathrm{~kg} \cdot \mathrm{ha}^{-1} \\
\text { as urea }\end{array}$ & & $\begin{array}{l}240 \mathrm{~N} \\
\mathrm{~kg} \cdot \mathrm{ha}^{-1} \\
\text { as urea }\end{array}$ & \\
\hline
\end{tabular}




\section{3 $\mathrm{NH}_{3}$ volatilization measurement}

$\mathrm{NH}_{3}$ was collected from October 2016 to June 2018 by the ventilation method. A polyvinyl chloride (PVC) cylinder (25 cm height, $15 \mathrm{~cm}$ diameter) was inserted $70 \mathrm{~mm}$ into the soil. The cylinder had a sponge soaked with phosphoglycerol (5\%, V/V, phosphoric acid and $4 \%$, V/V, glycerol) near its top to absorb ambient $\mathrm{NH}_{3}$ and one close to the bottom to collect $\mathrm{NH}_{3}$ from the soil (Dong et al., 2019). The sponges were collected each day for one week after each application of fertilizer and at each growth stage. The $\mathrm{NH}_{3}-\mathrm{N}$ that the sponges had trapped was extracted with $300 \mathrm{~mL}$ of $1 \mathrm{~mol} \cdot \mathrm{L}^{-1} \mathrm{KCL}$. The solution of $\mathrm{NH}_{4}{ }^{+} \mathrm{N}$ that had been extracted was analyzed with an AA3 continuous flow analyzer (Bran $\square$ Luebbe company, Germany). The flux of $\mathrm{NH}_{3}$ was calculated using the formula described by Yang et al (2020). The cumulative volatilization of $\mathrm{NH}_{3}$ was calculated as the integral sum of the

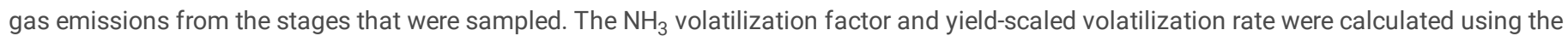
following formulas (Yang et al., 2020):

$\mathrm{NH}_{3}$ volatilizaiton factor $(\%)=\left(N_{\text {fertilizer }}-N_{\text {control }}\right) /\left(F_{n}\right)$

Yield-scale $\mathrm{NH}_{3}$ volatilizaiton $\left(\mathrm{kg} \mathrm{N} \mathrm{t}^{-1}\right.$ grain $)=N_{\text {fertilizer }} / G$

Where $\mathrm{N}_{\text {fertilizer }}$ and $\mathrm{N}_{\text {control }}$ are the total cumulative $\mathrm{NH}_{3}$ that had volatied during the entire wheat growing season under the treatment with nitrogen fertilizer and the control, respectively. $F_{n}$ is the total nitrogen that had been applied $\left(240 \mathrm{~kg} \cdot \mathrm{ha}^{-1}\right) . G$ is the grain yield.

\section{$2.4^{15} \mathrm{~N}$ measurement}

We conducted isotopic labeling microzone experiments with 15N urea during the wheat growing season in 2017 and 2018 . The micrograph (area size of $45 \mathrm{~cm} \times 15 \mathrm{~cm}$, depth, $30 \mathrm{~cm}$ ) was created using an iron sheet (Figure 3) and processed in the same manner as the field map. In A, ${ }^{15} \mathrm{~N}$-urea and urea were applied during the base dressing and jointing stages, respectively, and in $\mathrm{B}$, urea and ${ }^{15} \mathrm{~N}$-urea were applied during the base dressing and jointing, respectively, using the appropriate rates according to the treatment (Chen et al., 2019). In both wheat growing seasons, the plants were sampled from each micro-zone during the maturity stage. Each sample was first rinsed with running water and transported to the laboratory where they were dried in an oven at $105{ }^{\circ} \mathrm{C}$ for $30 \mathrm{~min}$ and subsequetly at $70{ }^{\circ} \mathrm{C}$ to a constant weight. In the final step, the sample is ground using a ball mill. Stable isotope tests were performed using an element analyzer (Flash 2000HT, Thermo Fisher Scientific, Waltham, MA, USA) and an isotope mass spectrometer (Delta V advantage, Thermo Fisher Scientific) to determine the ${ }^{15} \mathrm{~N}$ atomic percentage of the sample. Since the results of the two study growing seasons are similar, only 2017-2018 data are included here. All indexes were calculated using the formulas (Chen et al., 2019):

- $\operatorname{NDFF}(\%)=\left[\left(\mathrm{AT}^{15} \mathrm{~N}_{1}-0.3663\right) \times 100\right] /\left(\mathrm{AT} \%{ }^{15} \mathrm{~N}_{2}-0.3663\right)(1)$

- $\mathrm{NDF}\left(\mathrm{mg} \cdot \mathrm{stem}^{-1}\right)=\mathrm{NDFF} \times$ nitrogen content in plant components (2)

- NDFS=N uptake-NDF (3)

- NAAG=Grain weight $\times$ grain nitrogen content (4)

- TNAA=plant weight $\times$ plant nitrogen content (5)

- $\mathrm{SN}=\mathrm{NO}_{3}{ }^{-}$accumulation amount+ $\mathrm{NH}_{4}{ }^{+}$accumulation amount (6)

Where NDFF represents the percentage of nitrogen obtained from nitrogen fertilizer, AT\% ${ }^{15} \mathrm{~N}_{1}$ represents the atomic percentage of ${ }^{15} \mathrm{~N}$, and $A T \%{ }^{15} \mathrm{~N}_{2}$ represents the atomic percentage of ${ }^{15} \mathrm{~N}$ in the fertilizer. 0.3668 is the standard value of natural ${ }^{15} \mathrm{~N}$ abundance and $\mathrm{N}$ absorption is the total $\mathrm{N}$ in aboveground biomass. NDFF and NDF calculated microplots $\mathrm{A}$ (base fertilizer application ${ }^{15} \mathrm{~N}$ ) and $\mathrm{B}\left({ }^{15} \mathrm{~N}\right.$ applied at jointing) .

\subsection{Soil sample collection and preparation}

The soil from each treatment was sampled at the stages of wheat heading, anthesis and maturity (Meng et al., 2020). Each soil sample was a mixture of 5 randomly selected locations in a given plot. The soil samples were then passed through a $1 \mathrm{~mm}$ sieve for division into three fractions, mixed thoroughly, and stored at $4{ }^{\circ} \mathrm{C}$ for subsequent microbial biomass carbon or nitrogen ( $\mathrm{MBC}$ or $\left.\mathrm{MBN}\right)$, and inorganic $\mathrm{N}_{\text {content }}\left(\mathrm{NH}_{4}{ }^{+}\right.$and $\left.\mathrm{NO}_{3}{ }^{-}\right)$. An aliquot was air dried and urease activity and ${ }^{15} \mathrm{~N}$ abundance were determined through a 1-mm sieve. The last sample was freeze-dried and stored at $80{ }^{\circ} \mathrm{C}$ for subsequent DNA extraction and real-time PCR analysis.

\subsection{Total soil DNA extraction, q-PCR, and cloning of bacterial genes}

Soil DNA was extracted from each samples using a FastDNA Spin Kit for Soil (MP Biomedicals, LLC., Solon, OH, USA) according to the manufacturer's instructions. The DNA was then stored at $-80^{\circ} \mathrm{C}$ and analyzed within 3 days. A Nanodrop ${ }^{\circ} N D-2000$ UV-vis spectrophotometer (NanoDrop Technologies, Wilmington, DE, USA) was used to quantify the DNA and examine its purity. To quantify the abundance of Amoa-AOA, Amoa-AOB, nirS and nirK genes, quantitative poly-merase-chain-reaction (qPCR) assays were performed in triplicate using real-time PCR with a LightCycler 480 (Roche Applied Science). The conditions and primers are given in Table 2. The standard curves for real-time PCR were prepared as previously described (Li et al., 2017). A plasmid that contained 102-109copies $\mathrm{L}^{-1}$ was obtained by serial 10x dilutions. A q-PCR assay was then performed in triplicate to

Page $4 / 21$ 
provide an external standard curve for determine the numbers of unknown gene copies. The efficiency for amplification of target genes in the assays ranged from 92.3 to $105.2 \%$ and the $\mathrm{R}$ values were from 0.996 to 0.999 .

Table 2

Primers used for quantitative PCR

\begin{tabular}{|c|c|c|c|c|c|}
\hline $\begin{array}{l}\text { Targer } \\
\text { group }\end{array}$ & Primer & Sequence(5-3) & $\begin{array}{l}\text { Length } \\
\text { of } \\
\text { amplicon }\end{array}$ & $\begin{array}{l}\text { Thermal } \\
\text { profile }\end{array}$ & Reference \\
\hline $\begin{array}{l}\text { Amoa- } \\
\text { AOA }\end{array}$ & $\begin{array}{l}\text { Arch- } \\
\text { amoA26F/Arch- } \\
\text { amoA417R }\end{array}$ & GACTACATMTTCTAYACWGAYTGGGC/GGKGTCATRTATGGWGGYAAYGTTGG & 415 & $\begin{array}{l}5 \text { min at } \\
95^{\circ} \mathrm{C} \\
\text { followed } \\
\text { by } 40 \\
\text { cycles } \\
\text { of } 15 \mathrm{~s} \\
\text { at } 95^{\circ} \mathrm{C} \\
\text { and } 30 \mathrm{~s} \\
\text { at } 60^{\circ} \mathrm{C}\end{array}$ & $\begin{array}{l}\text { (Park et al., } \\
\text { 2008) }\end{array}$ \\
\hline $\begin{array}{l}\text { Amoa- } \\
\text { AOB }\end{array}$ & $\begin{array}{l}\text { amoA-F/amoA- } \\
\mathrm{R}\end{array}$ & GGGGTTTCTACTGGTGGT/CCCCTCKGSAAAGCCTTCTTC & 491 & $\begin{array}{l}5 \text { min at } \\
95^{\circ} \mathrm{C} \\
\text { followed } \\
\text { by } 40 \\
\text { cycles } \\
\text { of } 15 \mathrm{~s} \\
\text { at } 95^{\circ} \mathrm{C} \\
\text { and } 30 \mathrm{~s} \\
\text { at } 60^{\circ} \mathrm{C}\end{array}$ & $\begin{array}{l}\text { (Rotthauwe } \\
\text { et al., } \\
\text { 1997) }\end{array}$ \\
\hline nirk & nirK-1479yF & ATCGGCGGYRAAGGCGA & 164 & $\begin{array}{l}95^{\circ} \mathrm{C} \\
\text { for } 5 \\
\text { min, } 40 \\
\text { cycles } \\
\text { at } 95^{\circ} \mathrm{C} \\
\text { for } 5 \mathrm{~s} \text {, } \\
62^{\circ} \mathrm{C} \\
\text { for } 30 \mathrm{~s}, \\
95^{\circ} \mathrm{C} \\
\text { for } 10 \mathrm{~s} \\
(+0.3)\end{array}$ & $\begin{array}{l}\text { (Usyskin- } \\
\text { Tonne et } \\
\text { al., 2020) }\end{array}$ \\
\hline nirs & nirS128 43F & CTGCTCGGTCTGGCAGTT & 1622 & $\begin{array}{l}95^{\circ} \mathrm{C} \\
\text { for } 5 \\
\text { min, } 40 \\
\text { cycles } \\
\text { at } 95^{\circ} \mathrm{C} \\
\text { for } 5 \mathrm{~s} \text {, } \\
62^{\circ} \mathrm{C} \\
\text { for } 30 \mathrm{~s}, \\
95^{\circ} \mathrm{C} \\
\text { for } 10 \mathrm{~s} \\
(+0.3)\end{array}$ & $\begin{array}{l}\text { (Usyskin- } \\
\text { Tonne et } \\
\text { al., 2020) }\end{array}$ \\
\hline
\end{tabular}

\subsection{Potential nitrification rates (PNRs) and potential denitrification rates (PDRs)}

We conducted an in situ experiment on N mineralization during the growing season of winter wheat in 2017 and 2018 . Since most mineralization takes place in the top 2.5-5 cm of soil (Norton et al., 2004; Schimel and Parton, 1986), we focused on the potential nitrification rates (PNRs) and potential denitrification rates (PDRs) in the top $10 \mathrm{~cm}$ soil layer.

The PNRs was measured by shaking mud method (Yao et al., 2011). The PDRs were measured via by acetylene suppression technique (Liu et al., 2014). And the specific operation steps are determined according to Meng's method (Meng et al., 2020).

\subsection{Soil nitrogen invertase activit, $\mathrm{NO}_{3}{ }^{-}-\mathrm{N}$ and $\mathrm{NH}_{4}{ }^{+}-\mathrm{N}$, microbial biomass carbon and nitrogen}

At the same time as each $\mathrm{NH}_{3}$ volatilization sampling, three soil samples from each plot were collected from the top $10 \mathrm{~cm}$ of the soil, which was situated near the gas chambers, to determine the concentrations of $\mathrm{NO}_{3}{ }^{-}-\mathrm{N}$ and $\mathrm{NH}_{4}{ }^{+}-\mathrm{Nand}$ soil moisture. Soil moisture was determined gravimetric method by drying the soil at $105^{\circ} \mathrm{C}$ for $24 \mathrm{~h}$, and the results were expressed in grams of dry soil. The concentrations of $\mathrm{NH}_{4}{ }^{+}-\mathrm{N}^{-}$and $\mathrm{NO}_{3}{ }^{-}-\mathrm{N}_{\text {were }}$ measured using a continuous flow analytical system (Futura Continuous Flow Analytical System, Alliance Instruments, Eragny-Sur-Oise, France) after the samples had been extracted with $1 \mathrm{~mol} \cdot \mathrm{L}^{-1} \mathrm{KCL}$. The activity of urease was determined using indophenol blue. Two grams of soil (1-mm sieved and air-dried soil) were pre incubated with $1 \mathrm{~mL}$ of toluene for $15 \mathrm{~min}$ and $20 \mathrm{~mL}$ of PH 6.7 citrate buffer at $37^{\circ} \mathrm{C}$ for $3 \mathrm{~h}$. The cumulative $\mathrm{NH}_{4}{ }^{+}$ content was measured on a spectrophotometer at $690 \mathrm{~nm}$ using salicylic acid colorimetry. The activity of urease was expressed as $\mu \mathrm{g} \mathrm{NH}{ }_{4}^{+}-\mathrm{N} \mathrm{g}^{-1}$ dry 
soil $\mathrm{d}^{-1}$. The activities of nitrate reduxtase and nitrite reductase activities were assayed as described by Dominchin (2021). The MBC and MBN were measured by chloroform fumigation-extraction. The MBC was calculated as the difference in DOC levels between the samples that had been fumigated and a control thta had not with an efficiency factor of 0.45 . The MBN is calculated as the difference of total extractable nitrogen contents between fumigated soil and unfumigated soil, and the efficiency coefficient is 0.54 .

\subsection{Statistical analyses}

The effects of different split nitrogen fertilizer treatments on gene expression and biochemical parameters of key enzymes in nitrogen cycle were analyzed by SPSS v. 18.0 (IBM Corp., Armonk, NY, USA)

\section{Results}

\subsection{Ammonia volatilization}

The peak of daily $\mathrm{NH}_{3}$ was detected 2 days after each application of nitrogen fertilizer and then decreased to a relatively low levels 6-7 days after each application of nitrogen fertilizer (Figure 4). During this period, the $\mathrm{NH}_{3}$ fluxes ranged from 0.2 to $3.0 \mathrm{~kg} \mathrm{~N} \mathrm{ha}^{-1} \mathrm{~d}^{-1}$ and increased with increasing basal/topdressing nitrogen fertilizer ratio. Furthermore, the $\mathrm{NH}_{3}$ flux increased with increasing basal nitrogen fertilizer proportion between the sowing stage and jointing stage, as well as with increasing topdressing nitrogen fertilizer proportion from the jointing stage to the end of the experiment. This indicates that different treatments had significantly effect on $\mathrm{NH}_{3}$ volatilization losses from soil.

Table 3 presents the cumulative volatilization of $\mathrm{NH}_{3}$ under different treatments with split nitrogen during the 2017 and 2018 seasons of wheat growing. The cumulative losses of $\mathrm{NH}_{3}$ volatilization across all nitrogen treatments varied between 0.2 and $3.0 \mathrm{~kg} \mathrm{~N} \mathrm{ha}^{-1} \mathrm{~d}^{-1}(15.97-19.23 \%)$ in both growing seasons. The percent cumulative volatilization of $\mathrm{NH}_{3}$ under the $\mathrm{N} 3$ treatment was $5.56-13.42 \%$ and $5.22-10.83 \%$, lower than those under $\mathrm{N} 1$ or N2 and N4 or N5 treatments, respectively. Moreover, the largest decreases in the volatilization factor for $\mathrm{NH}_{3}$ and yield-scaled volatilization of $\mathrm{NH}_{3}$ were observed under the N3 treatment. N3 treatment decreased the volatilization factor for $\mathrm{NH}_{3}$ by $9.43-21.36 \%$ and the yield-scaled volatilization by $9.20-18.16 \%$ in both growing seasons compared with that under the N1 or N2 and N4 or N5 treatments, respectively. Similarly, under the N3 treatment, the yield-scaled $\mathrm{NH}_{3}$ volatilization decreased by $10.76-22.27 \%$ and $9.91-22.78 \%$ in both growing seasons, respectively.

Table 3

Effect of split nitrogen fertilizer on cumulative $\mathrm{NH}_{3}$ volatilization, $\mathrm{NH}_{3}$ volatilization factor and yield-scaled $\mathrm{NH}_{3}$ volatilization.

\begin{tabular}{|c|c|c|c|c|c|c|}
\hline \multirow[t]{2}{*}{ Year } & \multirow[t]{2}{*}{ Treatments } & \multicolumn{3}{|c|}{$\begin{array}{l}\text { Cumulative } \mathrm{NH}_{3} \text { volatilization } \\
\left(\mathrm{kg} \mathrm{N} \mathrm{ha}^{-1}\right)\end{array}$} & \multirow[t]{2}{*}{$\mathrm{NH}_{3}$ volatilization factor (\%) } & \multirow[t]{2}{*}{$\begin{array}{l}\text { Yield-scaled } \mathrm{NH}_{3} \text { volatilization } \\
\text { (kg N t}{ }^{-1} \text { grain) }\end{array}$} \\
\hline & & $\mathrm{BF}$ & TF & Total & & \\
\hline 2016- & $\mathrm{N} 1$ & $11.7 a$ & $3.64 \mathrm{e}$ & $19.23 a$ & $5.01 a$ & $2.56 a$ \\
\hline \multirow[t]{4}{*}{2017} & $\mathrm{~N} 2$ & $8.82 b$ & $5.62 d$ & $18.08 \mathrm{~b}$ & $4.53 b$ & $2.28 \mathrm{~b}$ \\
\hline & N3 & $6.81 c$ & $6.26 c$ & $16.65 c$ & $3.94 d$ & $1.99 c$ \\
\hline & N4 & $5.68 d$ & $8.14 b$ & $17.63 b$ & $4.35 c$ & $2.23 b$ \\
\hline & N5 & $3.07 e$ & $10.92 a$ & $17.95 b$ & $4.48 \mathrm{~b}$ & $2.49 a$ \\
\hline \multirow{5}{*}{$\begin{array}{l}2017- \\
2018\end{array}$} & N1 & $10.13 a$ & $3.91 \mathrm{e}$ & $17.91 \mathrm{a}$ & $4.46 a$ & $2.59 a$ \\
\hline & N2 & $7.81 b$ & $5.36 \mathrm{~d}$ & $16.87 \mathrm{~b}$ & $4.03 b$ & $2.22 \mathrm{c}$ \\
\hline & N3 & $6.13 c$ & $6.14 \mathrm{c}$ & $15.97 c$ & $3.65 c$ & $2.00 d$ \\
\hline & N4 & $5.38 d$ & $7.52 b$ & $16.85 b$ & $4.02 b$ & $2.27 \mathrm{c}$ \\
\hline & N5 & $3.04 \mathrm{e}$ & $9.73 a$ & $16.88 b$ & $4.06 \mathrm{~b}$ & $2.42 b$ \\
\hline
\end{tabular}

3.2 Effects of split nitrogen fertilizer on soil nitrification intensity, denitration intensity, abundance of nitrogen cycle functional genes and biochemical index

\subsubsection{Soil nitrification intensity and denitration intensity}

Fertilization strategy significantly affected soil nitrogen conversion (Figure 5). At the jointing stage, the nitrification and denitrification intensities increased with increasing topdressing nitrogen fertilizer proportion. At anthesis stage, the nitrification and denitrification intensities under the N3 
treatment were significantly lower than those under the N4 or N5 treatments, while the N1, N2, and N3 treatments did not differ significantly. At the maturity stage, the split nitrogen treatments did not result in any significant differences in nitrification intensity. Additionally, the denitrification intensity under the N3 treatment was significantly lower than that under N4 or N5 treatment, while that under N1, N2, and N3 treatments did not differ significantly.

\subsubsection{Abundance of nitrogen cycle functional genes}

Q-PCR based on the 16S rRNA gene was used to estimate the abundances of nitrogen cycle functional genes in soil under different split nitrogen fertilizer treatments (Figure 6). During the entire sampling process, changes in the Amoa-AOA, Amoa- $A O B$, nirK, and nirS counts in each group were similar, showing gradual decreases. The fertilization strategies did not significantly affect the $A m o a-A O A$ counts. In all treatments, the $A m o a-A O B$, nirK, and nirS counts at each stage increased with increasing proportion of topdressing nitrogen fertilizer at the jointing stage. During the anthesis and maturity stages, the Amoa-AOB, nirK, and nirS counts were significantly lower under the N3 treatment than those under the N4 or N5 treatments, and the N1, N2, and N3 treatments did not differ significantly. Hence, the one-time addition of excess nitrogen fertilization can increase the abundance of key genes for nitrification and denitrification. Moreover, a reasonable ratio of basal to topdressing nitrogen fertilizer (N3) can ensure that the numbers of these genes remain at a low level.

\subsubsection{Soil nitrogen invertase activity}

Differences were observed in soil nitrogen invertase activity among the split nitrogen fertilizer treatments (Figure 7). At the jointing stage, the urease content, nitrate reductase activity, nitrite reductase activity, and protease activity increased with increasing topdressing nitrogen fertilizer proportion. At the anthesis stage, the urease and protease activities under the N3 treatment were significantly higher than those under the N1 treatment, whereas the $\mathrm{N} 2, \mathrm{~N} 3, \mathrm{~N} 4$, and N5 treatments did not differ significantly. Moreover, the activities of nitrate reductase and nitrite reductase under the N3 treatment were significantly lower than those under the N4 or N5 treatments, however, no significant differences were observed among the N1, N2, and N3 treatments. The changes in soil nitrogen invertase activity during the maturity stage and the soil nitrogen invertase activity in the anthesis stage showed similar trends. These results demonstrate that N3 treatment leads to decreased activity of nitrate reductase and nitrite reductase in the soil, causing low intensity denitrification.

\subsubsection{Soil nitrate accumulation, ammonium nitrogen accumulation, soil microbial biomass $\mathrm{N}$ and $\mathrm{C}$}

At the jointing stage, the soil MBN, MBC, nitrate accumulation, and ammonium nitrogen accumulation increased with increasing topdressing nitrogen fertilizer proportion (Figure 8). Meanwhile, during the anthesis stage, the soil MBN under the N3 treatment was significantly higher than those under the other treatments. The soil MBC under N3 treatment was significantly higher than that under N1 or N2 treatment. However, no significant difference was observed among the N3, N4, and N5 treatments. Furthermore, the split nitrogen fertilizer treatments did not significantly affect nitrate or ammonium nitrogen accumulation. At the maturity stage, the soil MBN and MBC under the N3 treatment were higher than those of other treatments. Changes in the accumulation of nitrate and ammonium nitrogen showed similar trends.

\subsubsection{Relationship between nitrification intensity, denitration intensity and soil properties}

As revealed by Pearson correlation analysis (Figure 9), nitrification intensity positively correlated with the ammonia monooxygenase gene in the ammonia-oxidizing archaea ( $\mathrm{AOA}$ ) and ammonia-oxidizing bacteria ( $\mathrm{AOB})$, as well as with the Cu nitrate reductase gene, $c d_{1}$ nitrate reductase gene, nitrate reductase activity, ammonium nitrogen accumulation, and soil MBN and $\mathrm{MBCC}$, however, negatively correlated with protease activity and nitrate accumulation. The copies of nitrification intensity and denitrification intensity showed similar correlations with soil properties.

[IMAGE-C:\Workspace\ACDC\ImageHandler\9a

1: Ammonia monooxygenase gene in AOA populations; 2: Ammonia monooxygenase gene in AOB populations; 3: Cu nitrate reductase gene; 4: cd1 nitrate reductase gene; 5 : Urease content; 6 : Nitrate reductase activity; 7: Nitrite reductase activity; 8: Protease activity; 9 : Nitrate accumulation; 10: Ammonium nitrogen accumulation; 11: Soil microbial biomass N; 12: Soil microbial biomass C.

Figure 9. The relationship between soil properties and nitrification intensity, denitration intensity. *:Pख0.05;**: Pख0.01.

\subsection{Wheat nitrogen utilization by ${ }^{15} \mathrm{~N}$ tracer technique}

\subsubsection{Nitrogen absorption, utilization and residues in wheat-soil system}

As shown in Figure 10A, split nitrogen fertilizer treatment significantly affected nitrogen accumulation in wheat plant and grain. Compared with those under N1, N2, N4, or N5 treatment, the total plant nitrogen accumulation amount (TNAA) under N3 treatment increased by $19.89 \%, 7.20 \%, 10.74 \%$, and $21.81 \%$, respectively; while NAAG increased by $27.36 \%, 9.50 \%, 13.16 \%$, and $28.27 \%$, respectively.

Page $7 / 21$ 
In addition to the nitrogen obtained from other crops that fix nitrogen, the nitrogen in winter wheat primarily originates from the soil and nitrogen fertilizer. The plants treated with N3 absorbed the greatest amount of nitrogen from fertilizers and soil, followed by plants treated with N2 and N4, whereas the plants treated with N1 or N5 had the lowest levels. Moreover, the amount of nitrogen absorbed from basal/topdressing nitrogen fertilizer increased with increasing basal/topdressing nitrogen ratio. These results demonstrate that N3 treatment was more conducive to nitrogen nutrient uptake by wheat plants, resulting in high-yield and high-efficiency.

\subsection{2 ${ }^{15} \mathrm{~N}$ fertilizer in wheat plant-soil system}

We compared and analyzed the ratios of nitrogen fertilizer residue, plant recovery, and potential loss to nitrogen fertilizer application under the five treatments with split nitrogen (Figure 11). No significant difference was observed in the different ratios of nitrogen fertilizer residue to nitrogen fertilizer application. The ratio of plant recovery to nitrogen fertilizer application in N3 increased by $5.16-28.59 \%$ compared with those under N1, N2, N4, or N5 treatment. Similarly, under N3 treatment, the ratio of potential loss to nitrogen fertilizer application decreased by $12.81-24.73 \%$ compared with those under N1, N4, or N5 treatment. Increases in potential loss indicate that the significant loss of nitrogen to the atmosphere occurs through other channels, resulting in environmental issues.

\section{Discussion}

\subsection{The effect of split nitrogen fertilizer on ammonia volatilization}

Traditional methods of applying nitrogen fertilizer in winter wheat planting are often inefficient (Nkebiwe et al., 2016), whereas split nitrogen fertilization may be a promising method to improve grain yield while reducing nitrogen loss via $\mathrm{NH}_{3}$ volatilization (Afroz et al., 2014; Huda et al., 2016; Nkebiwe et al., 2016). Our results show that application of nitrogen fertilization had a significant influence on cumulative $\mathrm{NH}_{3}$ losses, which is consistent with the findings of Mkhabela et al. (2009). Cumulative $\mathrm{NH}_{3}$ loss from the different treatments accounted for 15.97 19.23\% of the total nitrogen inputs over the two years. In contrast, it was evident that $\mathrm{N} 3$ treatments has the ability to reduce $\mathrm{NH}_{3}$ losses by $5.22 \sim 13.42 \%$ of the cumulative $\mathrm{NH}_{3}$ volatilization, with significant reductions of $9.20 \sim 21.36 \%$ and $9.91 \sim 22.78 \%$ in both the volatilization of $\mathrm{NH}_{3}$ and that of yield-scaled $\mathrm{NH}_{3}$, respectively, under the $\mathrm{N} 3$ treatment over the two years. Hence, an appropriate split nitrogen fertilization scheme may decreases the rate of urea hydrolysis, which could contribute to decreases in $\mathrm{NH}_{3}$ volatilization.

It is evident that nitrogen loss via $\mathrm{NH}_{3}$ volatilization increases in conjunction with increasing proportions of basal or topdressing nitrogen (Li et al., 2018). Indeed, the current study was purposefully conducted in this region to demonstrate that $\mathrm{NH}_{3}$ volatilization from basal nitrogen fertilizer is higher than that from topdressing nitrogen fertilizer (Zhong et al., 2021). This may be due to immediate irrigation following topdressing nitrogen application causing infiltration of fertilizer into the deep soil, with a subsequent reduction in the amount of ammoniacal nitrogen in the top soil layer. This would consequently lower the losses from the volatilization of $\mathrm{NH}_{3}$, which supports the findings from previous studies (Holcomb et al., 2011). In our study, the peak of daily $\mathrm{NH}_{3}$ fluxes was identified 2 3 days after the application of $\mathrm{N}$ fertilizer, and they subsequently decreased to relatively low levels $6 \sim 7$ days after application. These results suggest that the loss of $\mathrm{NH}_{3}$ primarily occurs during the early period following nitrogen application. In general, the duration of our gas sampling measurements following nitrogen fertilizer application could effectively capture most of the $\mathrm{NH}_{3}$ volatilization induced by fertilizer application.

\subsection{The effect of split nitrogen fertilizer on nitrification intensity}

The nitrification intensity is a metric with the goal of determining the maximum capacity of nitrifiers in the transformation of ammonium (Li et al., 2018). Nitrogen fertilizer addition significantly alters the nitrification intensity at the stages of wheat jointing, anthesis and maturity, suggesting that nitrogen fertilizer affects the current season's wheat. The nitrification intensity at heading is significantly and negatively correlated with $\mathrm{N}$ uptake by wheat, showed that nitrification is an critical factor in the growth period of wheat (Yang et al., 2017).

$A O A$ and $A O B$ are two critical groups that participate in nitrification. The findings of our study indicate that nitrification activity was stimulated by large topdressing nitrogen fertilizer proportions and was accompanied by a significant increase in the abundance of $A O B$. AOB can frequently outcompete AOA for the inorganic nitrogen fertilizer (Hink et al., 2017). This competition can include the inhibition of AOA functions and growth, which prefer to use native soil $\mathrm{N}$ in contrast to an exogenous $\mathrm{N}$ source as a substrate (Fisk et al., 2015). The increase in soil nitrification could result in loss of nitrogen from agricultural systems and subsequent pollution of groundwater owing to nitrate leaching and denitrification. Our results also show that larger topdressing nitrogen fertilizer proportions produce a higher average accumulation of nitrate and ammonium in soil than other split nitrogen fertilizer ratios.

We demonstrated the inhibitory effect of the optimum split nitrogen fertilizer ratio on nitrification intensity from another perspective. The consequences of split nitrogen fertilizer on the microbial community structure in soil nitrification merit further study. Generally, the primary action of excess topdressing nitrogen fertilizer is to improve urea hydrolysis (Cantarella et al., 2018), and the results of this study suggest that the activity of urease also increases with the increasing topdressing nitrogen proportion.

\subsection{The effect of split nitrogen fertilizer on denitration intensity}

Page $8 / 21$ 
A substantial amount of previous research has shown that total $\mathrm{N}_{2} \mathrm{O}$ emissions positively correlated with soil denitrification intensity (Wang et al., 1991), which is closely related to the size of the pool labile $\mathrm{N}$ forms, such as $\mathrm{NH}_{4}{ }^{+} \mathrm{N}, \mathrm{NO}_{3}{ }^{-}-\mathrm{N}$, and $\mathrm{MBN}$. In this study, $\mathrm{N} 3$ treatment resulted in a significant decrease in the concentrations of $\mathrm{NH}_{4}{ }^{+}-\mathrm{N}_{\text {and }} \mathrm{NO}_{3}{ }^{-}-\mathrm{N}$, suggesting that this split nitrogen fertilizer ratio reduces urea degradation and that such treatment improves the absorption of $\mathrm{NH}_{4}{ }^{+}-\mathrm{N}, \mathrm{NO}_{3}{ }^{-}-\mathrm{N}$ ions and soluble organic $\mathrm{N}$ compounds (Lu et al., 2014; Liu et al., 2017; Li et al., 2018b). This relationship was confirmed by Harter et al. Who found that the emissions of $\mathrm{N}_{2} \mathrm{O}$ from the soil are indirectly reduced by a decrease in the concentrations of $\mathrm{NH}_{4}{ }^{+}-\mathrm{N}$ and $\mathrm{NO}_{3}{ }^{-}-\mathrm{N}$.

In our field trial, the N3 treatment significantly decreased the intensity of soil denitrification and the activities of soil nitrate reductase and nitrite reductase. These findings indicate that nitrate reductase and nitrite reductase in the soil play important roles in the amount of $\mathrm{N}_{2} \mathrm{O}$ that is emitted from the soil (Ding et al., 2011; Fan et al., 2018). The processes of soil denitrification are the primary sources of emissions by soil $\mathrm{N}_{2} \mathrm{O}$ (Cayuela et al., 2013; Wu et al., 2017a). Moreover, split nitrogen fertilizer can alter the rates of soil denitrification by altering the soil microbial and chemical properties of the soil (Nguyen et al., 2017; Li et al., 2018b). For example, managing nitrogen fertilizer appropriately can result in a reduction in the gross rates of soil denitrification by altering the community structure of soil AOB (Dempster et al., 2012; Li et al., 2018b).

Zhang et al. (2010b) also reported that nirk and nirS are the predominant genes in soil denitrification, the abundance of which was significantly reduced in our study following application of an optimal split nitrogen fertilizer ratio. A possible explanation for this observation could be that N3 treatment maintains the contents of $\mathrm{NH}_{4}{ }^{+}-\mathrm{N}$ and $\mathrm{NO}_{3}{ }^{-}-\mathrm{N}$ in the soil at a low level, and thus, denitrifying bacteria only have a low level of activity. Along with the increased soil denitrification rates following split nitrogen fertilizer application, these results suggest that $\mathrm{N} 3$ treatment decreases soil $\mathrm{N}_{2} \mathrm{O}$ emission by reducing nitrification and denitrification rates. Based on these data, we conclude that the optimal split nitrogen fertilizer application ratio decreases soil $\mathrm{N}$ losses by decreasing the concentrations of labile N, the activities of N-cycling enzymes, and the abundance of N-cycling key genes, as well as the rates of denitrification in wheat-land.

\subsection{The effect of split nitrogen fertilizer on wheat nitrogen utilization by ${ }^{15} \mathrm{~N}$ tracer technique}

In the ${ }^{15} \mathrm{~N}$ tracer experiment, separate applications of basal fertilizer ${ }^{15} \mathrm{~N}$ and topdressing fertilizer ${ }^{15} \mathrm{~N}$ were used to overcome an issue with the utilization of traditional fertilizers, which only examine the utilization of the total nitrogen fertilizer during the process of wheat growing. Based on measurements in soil samples and wheat plants, we estimated the applications of basal and topdressing nitrogen fertilizers in the wheat-soil system and the accumulation of nitrogen from basal/topdressing fertilizer in the system of wheat and soil. The results indicated that the N3 treatment resulted in a higher TNAA of wheat to fertilizer ${ }^{15} \mathrm{~N}$ than that under other split nitrogen fertilizer treatments. The TNAA in wheat was increased by $7.20-$ $21.81 \%$ relative to that from fertilizer ${ }^{15} \mathrm{~N}$, and NAAG (9.50-28.27\%) was the highest under N3 treatment. In addition, under N3 treatment, the nitrogen accumulation from soil increased by $7.20-27.45 \%$, compared with that under other split nitrogen fertilizer treatments. These results indicate that the N3 treatment contributes to a high accumulation of nitrogen by improving the absorption and utilization of soil and fertilizer nitrogen by wheat (Shi et al., 2012). In fact, a single application of excess fertilization resulted in a soil nitrogen surplus due to a difference in the supply of $\mathrm{N}$ supply and demand of the crop (Fageria et al., 2005).

Previous studies have shown that $\mathrm{NO}_{3}-\mathrm{N}$ leaching will lose excess $\mathrm{N}$ and pollute the environment (Oborn et al., 2003; Sieling et al., 2006). Our results indicate that the plants accumulate higher amounts of nitrogen when it is applied as topdressig rather than basal fertilizer. Thus, applications of basal $\mathrm{N}$ and high-level topdressing with $\mathrm{N}$ lead to a surplus of soil $\mathrm{N}$ and possibly loss via the leaching of $\mathrm{NO}_{3}-\mathrm{N}$, the loss of basal $\mathrm{N}$ results in a loss of $\mathrm{N}$ throughout the entire growing season due to the poor synchrony between the supply of $\mathrm{N}$ and the demand of crops. Further evidence suggests that altering the type of $\mathrm{N}$ fertilizer and applying it at the optimal rates for fertilization can meet the dual goals of sustaining the accumulation of nitrogen in crops and mitigating the volatilization of $\mathrm{NH}_{3}$ and greenhouse gases in winter wheat systems.

\section{Conclusion}

Compared with current conventional strategies, a cleaner nitrogen fertilization strategy for winter wheat production should decrease wheat-land soil $\mathrm{NH}_{3}$ volatilization while increasing grain yields and nitrogen accumulation to achieve sustainable agricultural development. In this study, N3 treatment significantly decreased soil $\mathrm{NH}_{3}$ volatilization as well as nitrification and denitrification intensities, while increasing nitrogen accumulation in grans in the winter wheat cropping system, resulting in a lower overall environmental burden. Thus, appropriately splitting nitrogen fertilizer applications under water-saving irrigation conditions is an effective fertilization strategy with benefits for both agronomy and the environment.

\section{Declarations}

Funding: This work was supported by the National Natural Science Foundation of China (31771717), the Natural Science Foundation of Shandong Province (ZR2016CM34), and China Agriculture Research System of MOF and MARA (CARS-3-1-19).

Conflicts of interest/Competing interests: Declaration of declare no conflict of interests. 
Authors' contributions: Data curation, Z. Z. (Zhen Zhang); formal analyses, Z. Z; founding acquisition, Y. Z. (Yongli Zhang) and Z. Y. (Zhenwen Yu); investigation, Z. Z. and Y. S. (Yu Shi); project administration, Y. Z.; writing original draft, Z. Z.; writing review \& editing, Z. Z., Z. Y., Y. Z., Y. S. All authors have read and agreed to the published version of the manuscript.

Data availability: The datasets used or analysed during the current study are available from the corresponding author on reasonable request.

\section{References}

1. Abdo Al, Shi DP, Li J, Yang T, Wang XF, Li HT, Abdel-hamed EMW, Merwad AMA, Wang LQ (2020) Ammonia emission from staple crops in China as response to mitigation strategies and agronomic conditions: Meta-analytic study. Journal of Cleaner Production 279:123835. http://doi.org/10.1016/j.jclepro.2020.123835

2. Fu H, Luo Z, Hu S (2020) A temporal-spatial analysis and future trends of ammonia emissions in China. Sci Total Environ 731-138897. http://doi.org/10.1016/j.scitotenv.2020.138897

3. Behera SN, Sharma M, Aneja VP, Balasubramanian R (2013) Ammonia in the atmosphere: a review on emission sources, atmospheric chemistry and deposition on terrestrial bodies. Environ Sci Pollut R 20:8092-8131. http://doi.org/10.1007/s11356-013-2051-9

4. Ti C, Xia L, Chang SX, Yan X (2018) Potential for mitigating global agricultural ammonia emission: A meta-analysis. Environ Pollut 245:141-148. http://doi.org/10.1016/j.envpol.2018.10.124

5. Wu W, Ma BL, Fan JJ, Sun M, Yi Y, Guo WS, Voldeng HD (2019) Management of nitrogen fertilization to balance reducing lodging risk and increasing yield and protein content in spring wheat. Field Crop Res 241:107584. http://doi.org/10.1016/j.fcr.2019.107584

6. Sun C, Chen L, Zhai LM, Liu HB, Wang K, Jiao C, Shen ZY (2020) National assessment of nitrogen fertilizers fate and related environmental impacts of multiple pathways in China. Journal of Cleaner Production S 0959-6526(20):33564-33562.

http://doi.org/10.1016/j.jclepro.2020.123519

7. Liu W, Yang H, Liu J, Azevedo LB, Wang X, Xu Z, Abbaspour KC, Schulin R (2016) Global assessment of nitrogen losses and trade-offs with yields from major crop cultivations. Sci Total Environ 572:526-537. http://doi.org/10.1016/j.scitotenv.2016.08.093

8. Xia L, Ti C, Li B, Xia Y, Yan X (2016) Greenhouse gas emissions and reactive nitrogen releases during the life-cycles of staple food production in China and their mitigation potential. Sci Total Environ 556:116-125. http://doi.org/10.1016/j.scitotenv.2016.02.204

9. Peng S, Buresh RJ, Huang J, Yang J, Zou Y, Zhong X, Wang G, Zhang F (2006) Strategies for overcoming low agronomic nitrogen use efficiency in irrigated rice system in China. Field Crop Res 96:37-47. http://doi.org/10.1016/j.fcr.2005.05.004

10. Fan C, Li B, Xiong Z (2018) Nitrification inhibitors mitigated reactive gaseous nitrogen intensity in intensive vegetables soils from China. Sci Total Environ 612:480-489. http://doi.org/10.1016/j.scitotenv.2017.08.159

11. Yadvinder-Singh, Kukal SS, Jat ML, Sidhu HS (2014) Improving water productivity of wheat-based cropping systems in South Asia for sustained productivity. ADV, Agron 127:157-258. http://doi.org/10.1016/B978-0-12-800131-8.00004-2

12. Scheer C, Grace PR, Rowlings DW, Payero J (2012) Nitrous oxide emissions from irrigated wheat in Australia: impact of irrigation management. Plant Soil 359:351-362. http://doi.org/10.1007/s11104-012-1197-4

13. Guo ZJ, Shi Y, Yu ZW, Zhang YL (2015) Supplemental irrigation affected flag leaves senescence post-anthesis and grain yield of winter wheat in the Huang-huai-hai Plain of China. Field Crop Res 180:100-109. http://doi.org/10.1016/j.fcr.2015.05.015

14. Man JG, Wang D, White PJ, Yu ZW (2014) The length of micro-sprinkling hoses delivering supplemental irrigation affects photosynthesis and dry matter production of winter wheat. Field Crop Res 168:65-74. http://doi.org/10.1016/j.fcr.2014.08.012

15. Meng XT, Li YY, Yao HY, Wang J, Dai F, Wu YP, Chapman S (2020) Nitrification and urease inhibitors improve rice nitrogen uptake and prevent denitrification in alkaline paddy soil. Appl Soil Ecol 154. http://doi.org/10.1016/j.apsoil.2020.103665

16. Hu R, Wang XP, Xu JS, Zhang YF, Pan YX, Su X (2020) The mechanism of soil nitrogen transformation under different biocrusts to warming and reduced precipitation: from microbial functional genes to enzyme activity. Sci Total Environ 722:137849. http://doi.org/10.1016/j.scitotenv.2020.137849

17. Fang X, Zhou GY, Li TL, Liu SZ, Chu GW, Xu ZH (2016) Warming effects on biomass and composition of microbial communities and enzyme activities within soil aggregates in subtropical forest. Biol Fertil Soils 52:353-365. http://doi.org/10.1007/s00374-015-1081-5

18. Fierer N, Leff JW, Adams B, J.,Nielsen UN, Bates ST, Lauber CL (2012) Crossbiome metagenomic analyses of soil microbial communities and their functional attributes. Proc. Natl. Acad. Sci. U. S. A. 109, 21390-21395. http://doi.org/10.1073/pnas.1215210110

19. Waldrop MP, Holloway JM, Smith DB, Goldhaber MB, Drenovsky RE, Scow KM (2017) The interacting roles of climate, soils, and plant production on soil microbial communities at a continental scale. Ecology 98:1957-1967. http://doi.org/10.1002/ecy.1883

20. Weedon JT, Kowalchuk GA, Aerts R, Van Han J, Van Logtestijn R, Tas N (2012) Summer warming accelerates sub-arctic peatland nitrogen cycling without changing enzyme pools or microbial community structure. Glob Chang Biol 18:138-150. http://doi.org/10.1111/j.13652486.2011.02548.x

21. Streit K, Hagedorn F, Hiltbrunner D, Portmann M, Saurer M, Buchmann N (2014) Soil warming alters microbial substrate use in alpine soils. Glob Chang Biol 20:1327-1338. http://doi.org/10.1111/gcb.12396

Page 10/21 
22. Canarini A, Kiaer LP, Dijkstra FA (2017) Soil carbon loss regulated by drought intensity and available substrate: a meta-analysis. Soil Biol Biochem 112:90-99. http://doi.org/10.1016/j.soilbio.2017.04.020

23. Liu YB, Zhao LN, Wang ZR, Liu LC, Zhang P, Sun JY (2018) Changes in functional gene structure and metabolic potential of the microbial community in biological soil crusts along a revegetation chronsequence in the tengger desert. Soil Biol Biochem 126:40-48. http://doi.org/10.1016/j.soilbio.2018.08.012

24. Nie M, Pendall E, Bell C, Gasch CK, Raut S, Tamang S (2013) Positive climate feedbacks of soil microbial communities in a semi-arid grassland. Ecol Lett 16:234-241. http://doi.org/10.1111/ele.12034

25. Petersen DG, Blazewicz SJ, Firestone M, Heman DJ, Turetsky M, Waldrop M (2012) Abundance of microbial genes associated with nitrogen cycling as indices of biogeochemical process rates across a vegetation gradient in Alaska. Environ Microbiol 14:993-1008. http://doi.org/10.1111/j.1462-2920.2011.02679.x

26. Tu QC, He ZL, Wu LY, Xue K, Xie G, Chain P (2017) Metagenomic reconstruction of nitrogen cycling pathways in a $\mathrm{CO}_{2}$ - enriched grassland ecosystem. Soil Biol Biochem 106:99-108. http://doi.org/10.1016/j.soilbio.2016.12.017

27. Xue K, Yuan MM, Shi ZJ, Qin YJ, Deng Y, Cheng L (2016) Tundra soil carbon is vulnerable to rapid microbial decpmposition under climate warming. Nat Clim Chang 6:595-600. http://doi.org/10.1038/nclimate2940

28. Fraser TD, Lynch DH, Bent E, Entz MH, Dunfield KE (2015) Soil bacterial phoD gene abundance and expression in response to applied phosphorus and long-term management. Soil Biol Biochem 88:137-147. http://doi.org/10.1016/j.soilbio.2015.04.014

29. Fraser TD, Lynch DH, Gaiero J, Khosla K, Dunfield KE (2017) Quantification of bacterial non-specific acid (phoC) and alkaline (phoD) phosphatases genes in bulk and rhizosphere soil from organically managed soybean fields. Appl Soil Ecol 111:48-56. http://doi.org/10.1016/j.apsoil.2016.11.013

30. Maougal RT, Plassard C, Abadie J, Djekoun A, Drevon JJ (2014) Bacterial capacities to mineralize phytase increase in the rhizosphere of nodulated common bean (Phaseolus vulgaris) under P deficiency. Eur J Soil Biol 62:8-14. http://doi.org/10.1016/j.ejsobi.2014.02.006

31. Neal AL, Rossmann M, Brearley C, Akkari E, Guyomar C, Clark IM (2017) Landuse influences phosphatase gene microdiversity in soils. Environ Microbiol 19:2740-2753. http://doi.org/10.1111/1462-2920.13778

32. Luo G, Ling N, Nannipieri P, Chen H, Raza W, Wang M (2017) Long-term fertilisation regimes affect the composition of the alkaline phosphomonoesterase encoding microbial community of a vertisol and its derivative soil fractions. Biol Fertil Soils 53:375-388. http://doi.org/10.1007/s00374-017-1183-3

33. Wei X, Hu Y, Razavi BS, Zhou J, Shen J, Nannipieri P, Wu J, Ge T (2019) Rare taxa of alkaline phoshomonoesterase-harboring microorganisms mediate soil phosphorus mineralization. Soil Biol Biochem 131:62-70. http://doi.org/10.1016/j.soilbio.2018.12.025

34. Wei Y, Zhao Y, Shi M, Gao Z, Lu Q, Yang T (2018) Effect of organic acids production and bacterial community on the possible mechanism of phosphorus solubilization during composting with enriched phosphate-solubilizing bacteria inoculation. Bioresour Technol 247:190-199. http://doi.org/10.1016/j.biotech.2017.09.092

35. Wang Y, Zhao X, Guo Z, Jia Z, Wang S, Ding K (2018) Response of soil microbes to a reduction in phosphorus fertilizer in rice-wheat rotation paddy soils with varying soil $P$ levels. Soil Till Res 181:127-135. http://doi.org/10.1016/j.still.2018.04.005

36. Hu Y, Xia Y, Sun Q, Liu K, Chen X, Ge T (2018) Effects of long-term fertilization on phoD-harboring bacterial community in Karst soils. Sci Total Environ 628-629:53-63. http://doi.org/10.1016/j.scitotenv.2018.01.314

37. Dong YB, Wu Z, Zhang X, Feng L, Xiong ZQ (2019) Dynamic responses of ammonia volatilization to different rates of fresh and field-aged biochar in a rice-wheat rotation system. Field Crop Res 241:107568. http://doi.org/10.1016/j.fcr.2019.107568

38. Yang GY, Ji HT, Sheng J, Zhang YF, Feng YF, Guo Z, Chen LG (2020) Combining azolla and urease inhibitor to reduce ammonia volatilization and increase nitrogen use efficiency and grain yield of rice. Science of the Total Environment 743:140799.

http://doi.org/10.1016/j.scitotenv.2020.140799

39. Chen P, Nie TZ, Chen SH, Zhang ZX, Qi ZJ, Liu WN (2019) Recovery efficiency and loss of 15N-labelled urea in a rice-soil system under water saving irrigation in the Songnen Plain of Northeast China. Agricultural Water Management 222:139-153.

http://doi.org/10.1016/j.agwat.2019.04.026

40. Meng XT, Li YY, Yao HY, Wang J, Dai F, Wu YP, Chapman S (2020) Nitrification and urease inhibitors improve rice nitrogen uptake and prevent denitrification in alkaline paddy soil. Appl Soil Ecol 154:103665. http://doi.org/10.1016/j.apsoil.2020.103665

41. Li J, Huang B, Wang QX, Li Y, Fang WS, Han DW, Yan DD, Guo MX, Cao AC (2017) Effects of fumigation with metam-sodium on soil microbial biomass, respiration, nitrogen transformation, bacterial community diversity and genes encoding key enzymes involved in nitrogen cycling. Science of The Total Environment 598:1027-1036. http://doi.org/10.1016/j.scitotenv.2017.02.058

42. Park SJ, Park BJ, Rhee SK (2008) Comparative analysis of archaeal 16 S rRNA and amoA genes to estimate the abundance and diversity of ammonia-oxidizing archaea in marine sediments. Extremophiles 12:605-615. http://doi.org/10.1007/s00792-008-0165-7

43. Rotthauwe JH, Witzel KP, Liesack W (1997) The ammonia monooxygenase structural gene amoA as a functional marker, molecular fine-scale analysis of natural ammonia-oxidizing populations. Applied Environmental Microbiology 63:4704-4712.

http://doi.org/10.1126/science.284.5411.63

Page $11 / 21$ 
44. Usyskin-Tonne A, Hadar Y, Yermiyahu U, Minz D (2020) Elevated $\mathrm{CO}_{2}$ has a significant impact on denitrifying bacterial community in wheat roots. Soil Biol Biochem 142:107697. http://doi.org/10.1016/j.soilbio.2019.107697

45. Yao Y, Gao Y, Nicol GW, Campbell CD, Prosser JI, Zhang L, Han W, Singh BK (2011) Links between ammonia oxidizer community structure, abundance, and nitrification potential in acidic soils. Appl Environ Microbiol 77:4618-4625. http://doi.org/10.1128/AEM.00136-11

46. Liu L, Wang D, Deng H, Li Y, Chang S, Wu Z, Yu L, Hu Y, Yu Z, Chen Z (2014) The capability of estuarine sediments to remove nitrogen: implications for drinking water resource in Yangtze Estuary. Environ Sci Pollut Res 21:10890-10899. http://doi.org/10.1007/s11356-014-2914-8

47. Norton JB, Monaco TA, Johnson DA, Jones TA (2004) Soil morphology and organic matter dynamics under cheatgrass and sagebrush-steppe plant communities. J Arid Environ 57:445-466. http://doi.org/10.1016/S0140-1963(03)00104-6

48. Schimel J, Balser TC, Wallenstein M (2007) Microbial stress-response physiology and its implications for ecosystem function. Ecology 88:13861394. http://doi.org/10.1089/06-0219

49. Afroz H, Islam MR (2014) Floodwater nitrogen, rice yield and N use efficiency as influenced by deep placement of nitrogenous fertilizers. J Environ Sci Nat Resour 7:207-213

50. Huda A, Gaihre YK, Islam MR, Singh U, Islam MR, Sanabria J, Satter MA, Afroz H, Halder A, Jahiruddin M (2016) Floodwater ammonium, nitrogen use efficiency and rice yields with fertilizer deep placement and alternate wetting and drying under triple rice cropping system. Nutr Cycling Agroecosyst 104:53-66. http://doi.org/10.1007/s10705-015-9758-6

51. Nkebiwe PM, Welnmann M, Bar-Tal A, Muller T (2016) Fertilizer placement to improve crop nutrient acqulsition and yield, a review and metaanalysis. Field Crop Res 196:389-401. http://doi.org/10.1016/j.fcr.2016.07.018

52. Mkhabela MS, Gordon R, Burton D, Smith E, Madani A (2009) The impact of management practices and meteorological conditions on ammonia and nitrous oxide emissions following application of hog slurry to forage grass in nova scotia. Agric Ecosyst Environ 130:41-49. http://doi.org/10.1016/j.agee.2008.11.012

53. Li MN, Wang YL, Adeli A, Yan HJ (2018) Effects of application methods and urea rates on ammonia volatilization, yields and fine root biomass of alfalfa. Field Crop Res 218:115-125. http://doi.org/10.1016/j.fcr.2018.01.011

54. Zhong XM, Zhou X, Fei JC, Huang Y, Wang G, Kang XR, Hu WF, Zhang HR, Rong XM, Peng JW (2021) Reducing ammonia volatilization and increasing nitrogen use efficiency in machine-transplanted rice with side-deep fertilization in a double-cropping rice system in Southern China. Agriculture Ecosystems and Environment. http://doi.org/10.1016/j.agee.2020.107183

55. Dominchin MF, Verdenelli RA, Berger MG, Aoki A, Meriles JM (2021) Impact of N-fertilization and peanut shell biochar on soil microbial community structure and enzyme activities in a Typic Haplustoll under different management practices. Eur J Soil Biol 104:103298. http://doi.org/10.1016/j.ejsobi.2021.103298

56. Holcomb JC, Dan MS, Horneck DA, Clough GH (2011) Effect of irrigation rate on ammonia volatilization. Soil Sci Soc Am J 75:2341-2347. http://doi.org/10.2136/sssaj2010.0446

57. Shi ZL, Li DD, Jing Q, Cai J, Jiang D, Cao WX, Dai TB (2012) Effects of nitrogen applications on soil nitrogen balance and nitrogen utilization of winter wheat in a rice-wheat rotation. Field Crop Res 127:241-247. http://doi.org/10.1016/US2806767A

58. Fageria NK, Baligar VC (2005) Enhancing nitrogen use efficiency in crop plants. Adv Agron 88:97-185. http://doi.org/10.1016/S00652113(05)88004-6

59. Oborn I, Edwards AC, Witter E, Oenema O, Ivarsson K, Withers PJA, Nilsson SI, Richert Stinzing A (2003) Element balances as a tool for sustainable nutrient management: a critical appraisal of their merits abd limitations within an agronomic and environmental context. Eur J Agron 20:211225

60. Sieling K, Kage H (2006) N balance as an indicator of $\mathrm{N}$ leaching in an oilseed rape-winter wheat-winter barley rotation. Agric Ecosyst Environ 115:261-269. http://doi.org/10.1016/j.agee.2006.01.011

61. Cantarella H, Otto R, Soares JR, Silva AG (2018) Agronomic efficiency of NBPT as a urease inhibitor: a review. J Adv Res 13:19-27. http://doi.org/10.1016/j.jare.2018.05.008

62. Fisk LM, Maccarone LD, Barton L, Murphy DV (2015) Nitrapyrin decreased nitrification of nitrogen released from soil organic matter but not amoA gene abundance at high soil temperature. Soil Biol Biochem 88:214-223. http://doi.org/10.1016/j.soilbio.2015.05.029

63. Hink L, Nicol GW, Prosser JI (2017) Archaea produce lower yields of $\mathrm{N}_{2} \mathrm{O}$ than bacteria during aerobic ammonia oxidation in soil: $\mathrm{N}_{2} \mathrm{O}$ production by soil ammonia oxidisers. Environ Microbiol 19:4829-4837. http://doi.org/10.1111/1462-2920.13282

64. Jiang X, Hou X, Zhou X, Xin X, Wright A, Jia Z (2015) pH regulates key players of nitrification in paddy soils. Soil Biol Biochem 81:9-16. http://doi.org/10.1016/j.soilbio.2014.10.025

65. Li Y, Chapman SJ, Nicol GW, Yao H (2018) Nitrification and nitrifiers in acidic soils. Soil Biol Biochem 116:290-301. http://doi.org/10.1016/j.soilbio.2017.10.023

66. Yang Y, Meng T, Qian X, Zhang J, Cai Z (2017) Evidence for nitrification ability controlling nitrogen use efficiency and N losses via denitrification in paddy soils. Biol Fertil Soils 53:349-356. http://doi.org/10.1007/s00374-017-1185-1

67. Cayuela ML, Sánchez-Monedero MA, Roig A, Hanley K, Enders A, Lehmann J (2013) Biochar and denitrification in soils: when, how much and why does biochar reduce $\mathrm{N}_{2} \mathrm{O}$ emissions. Sci Rep 3:1732. http://doi.org/10.1038/srep01732

Page 12/21 
68. Cai XQ, Lin ZW, Penttinen P, Li YF, Li YC, Luo Y, Yue T, Jiang PK, Fu WJ (2018) Effects of conversion from a natural evergreen broadleaf forest to a Moso bamboo plantation on the soil nutrient pools, microbial biomass and enzyme activities in a subtropical area. Forest Ecol Manag 422:161171. http://doi.org/10.1016/j.jclepro.2020.123835

69. Ding WX, Hongyan YY, Cai ZC (2011) Impact of urease and nitrification inhibitors on nitrous oxide emissions from fluvo-aquic soil in the North China plain. Biol Fert Soils 47:91-99. http://doi.org/10.1007/s00374-010-0504-6

70. Dempster DN, Gleeson DB, Solaiman ZI, Jones DL, Murphy DV (2012) Decreased soil microbial biomass and nitrogen mineralisation with Eucalyptus biochar addition to a coarse textured soil. Plant Soil 354:311-324. http://doi.org/10.1007/s11104-011-1067-5

71. Fan XP, Yin C, Yan GC, Cui PY, Shen Q, Wang Q, Chen H, Zhang N, Ye MJ, Zhao YH, Li TQ, Liang YC (2018) The contrasting effects of N-(n-butyl) thio-phosphoric triamide (NBPT) on $\mathrm{N}_{2} \mathrm{O}$ emissions in arable soils differing in pH are underlain by complex microbial mechanisms. Sci Total Environ 642:155-167. http://doi.org/10.1016/j.scitotenv.2018.05.356

72. Harter J, Krause HM, Schuettler S, Ruser R, Fromme M, Scholten T, Kappler A, Behrens S (2014) Linking $\mathrm{N}_{2} \mathrm{O}$ emissions from biochar-amended soil to the structure and function of the N-cycling microbial community. ISME J 8:660-674. http://doi.org/10.1038/ismej.2013.160

73. Li YF, Hu SD, Chen JH, Müller K, Li YC, Fu WJ, Lin ZW, Wang HL (2018b) Effects of biochar application in forest ecosystems on soil properties and greenhouse gas emissions: a review. J Soils Sediments 18:546-563. http://doi.org/10.1007/s11368-017-1906-y

74. Liu Q, Liu BJ, Zhang YH, Lin ZB, Zhu TB, Sun RB, Wang XJ, Ma J, Bei QC, Liu G, Lin XW, Xie ZB (2017) Can biochar alleviate soil compaction stress on wheat growth and mitigate soil $\mathrm{N}_{2} \mathrm{O}$ emissions? Soil Biol Biochem 104:8-17. http://doi.org/10.1016/j.soilbio.2016.10.006

75. Lu WW, Ding WX, Zhang JH, Li Y, Luo JF, Bolan N, Xie ZB (2014) Biochar suppressed the decomposition of organic carbon in a cultivated sandy loam soil: a negative priming effect. Soil Biol Biochem 76:12-21

76. Nguyen TTN, Xu CY, Tahmasbian I, Che RX, Xu ZH, Zhou XH, Wallace HM, Bai HS (2017) Effects of biochar on soil available inorganic nitrogen: a review and meta-analysis. Geoderma 288:79-96. http://doi.org/10.1016/j.geoderma.2016.11.004

77. Wei XM, Bahar SR, Hu YJ, Xu XL, Zhu ZK, Liu YH, Yakov K, Li Y, Wu JS, Ge TD (2019) C/P stoichiometry of dying rice root defines the spatial distribution and dynamics of enzyme activities in root-detritusphere. Biol Fert Soils 55:251-263. http://doi.org/10.1007/s00374-019-01345-y

78. Wu D, Senbayram M, Well R, Brüggemann N, Pfeiffer B, Loick N, Stempfhuber B, Dittert K, Bol R (2017a) Nitrification inhibitors mitigate $\mathrm{N}_{2} \mathrm{O}$ emissions more effectively under straw-induced conditions favoring denitrification. Soil Biol Biochem 104:197-207. http://doi.org/10.1016/j.soilbio.2016.10.022

79. Zhu ZK, Ge TD, Luo Y, Liu SL, Xu XL, Tong CL, Shibistova O, Guggenberger G, Wu JS (2018) Microbial stoichiometric flexibility regulates rice straw mineralization and its priming effect in paddy soil. Soil Biol Biochem 121:67-76. http://doi.org/10.1016/j.soilbio.2018.03.003

\section{Figures}




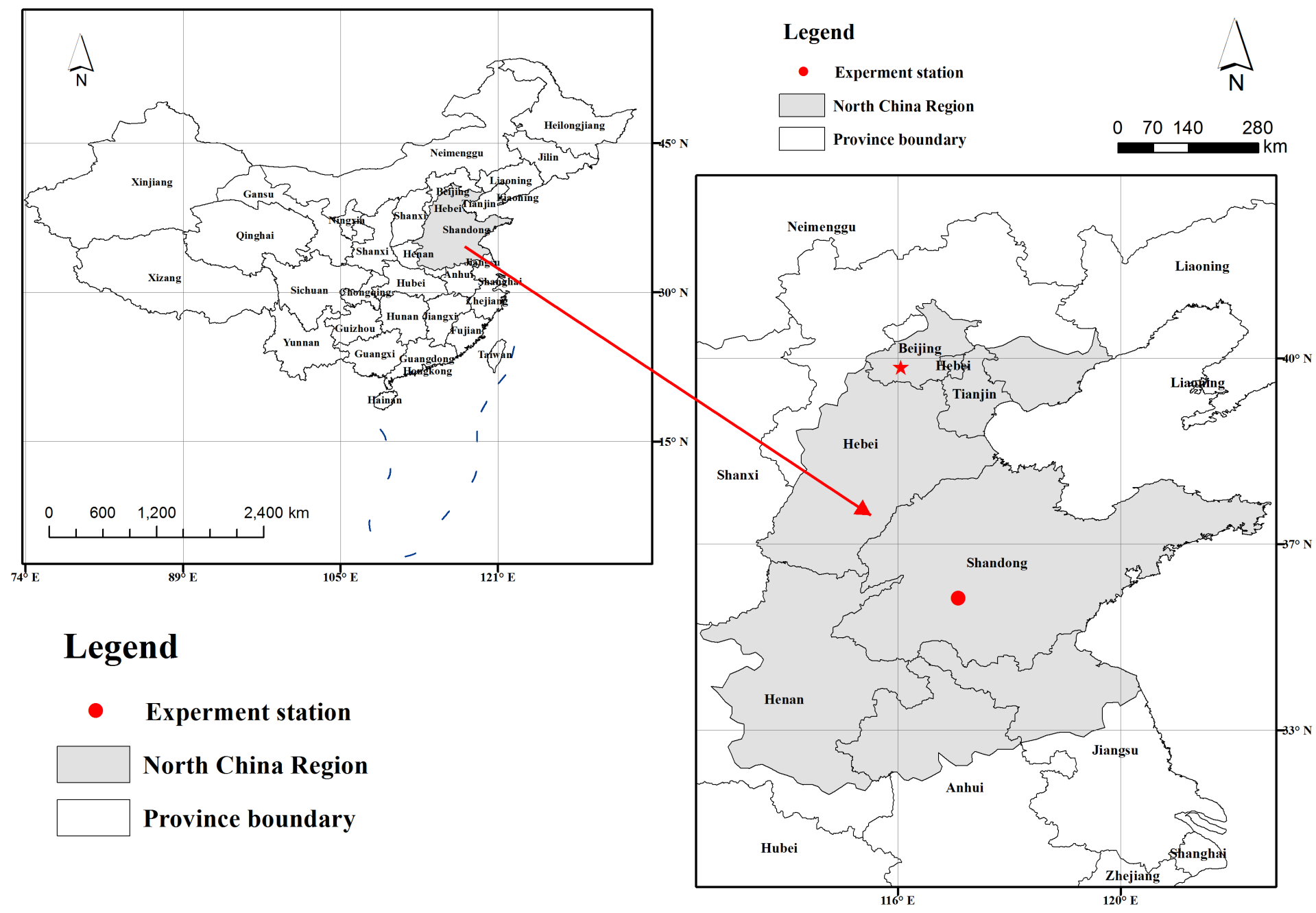

Figure 1

Map showing the study site.



Figure 2

Effective precipitation and temperature during wheat growth period. 


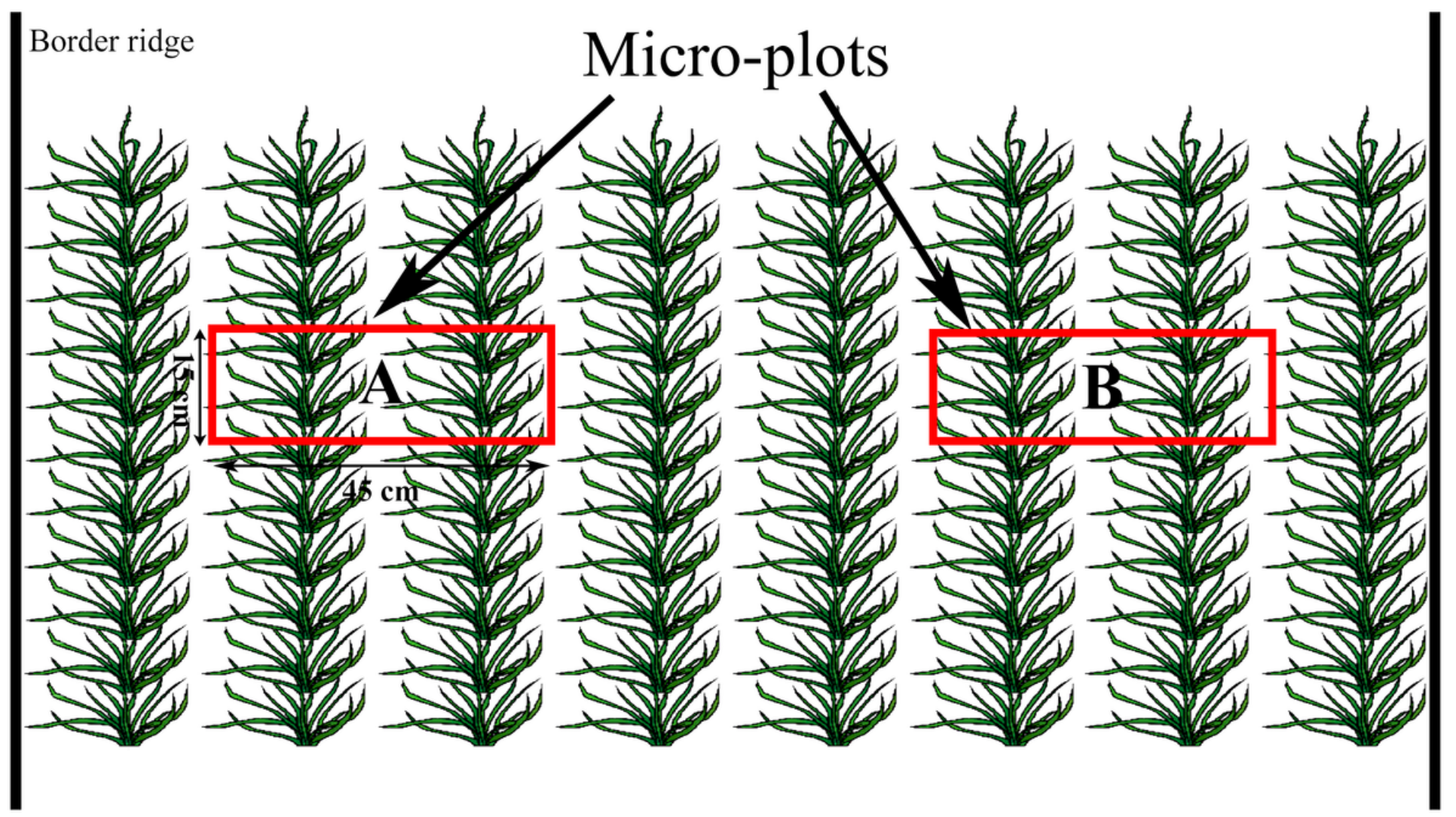

Figure 3

Map showing the micro-plots. 

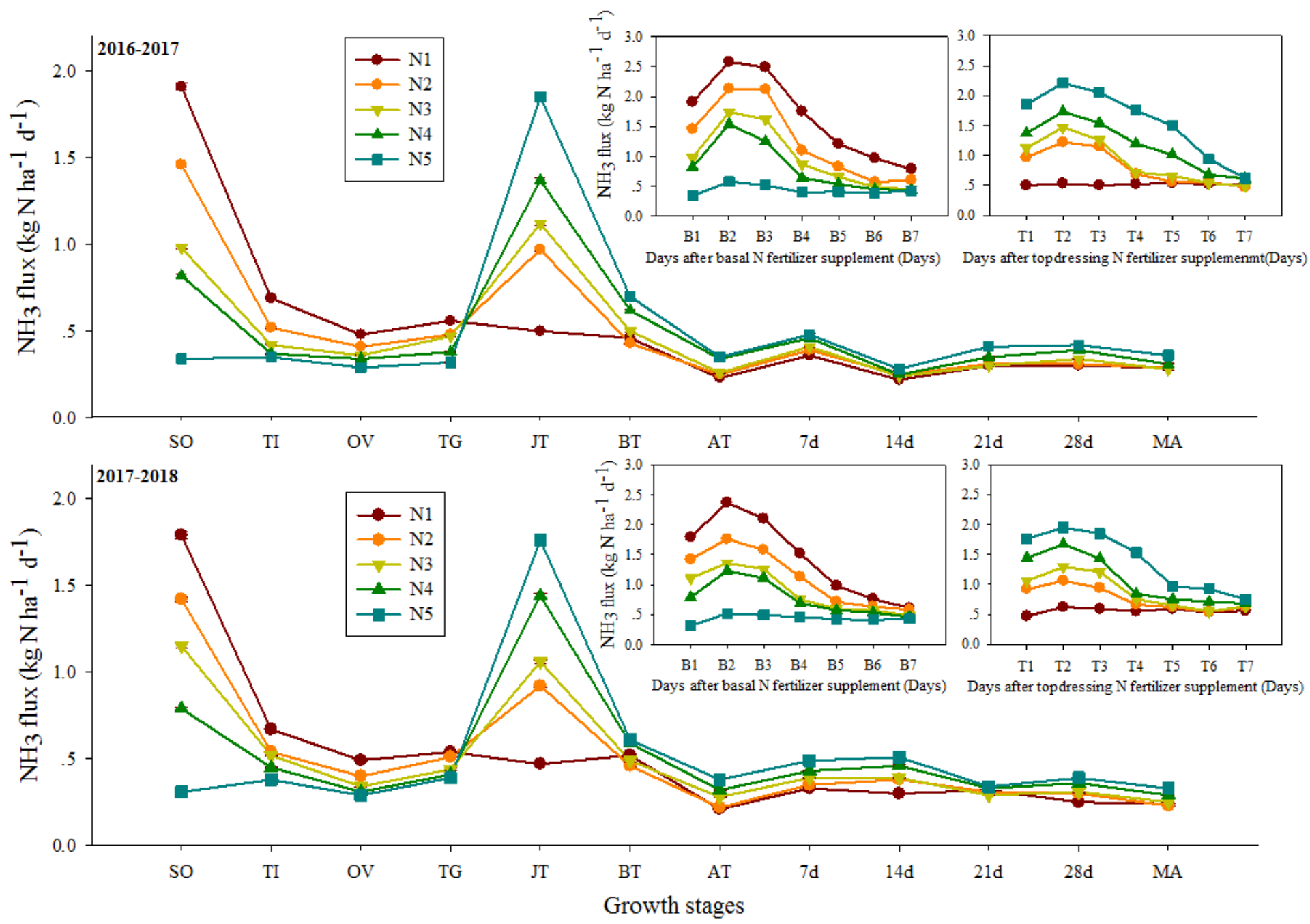

\section{Figure 4}

Effect of split nitrogen fertilizer on NH3 flux. 


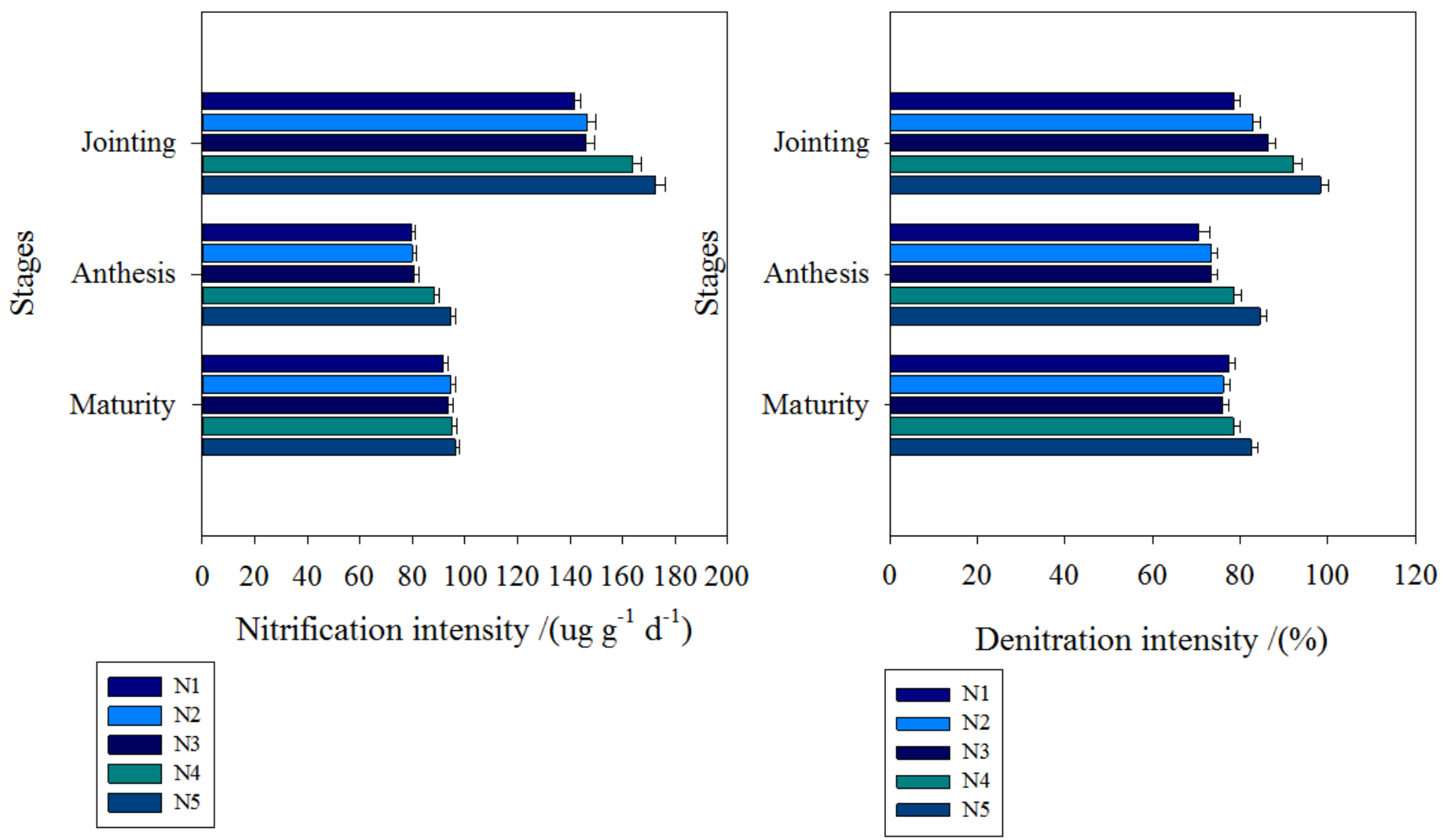

Figure 5

The effects of split nitrogen fertilizer on the nitrification intensity and denitration intensity. 

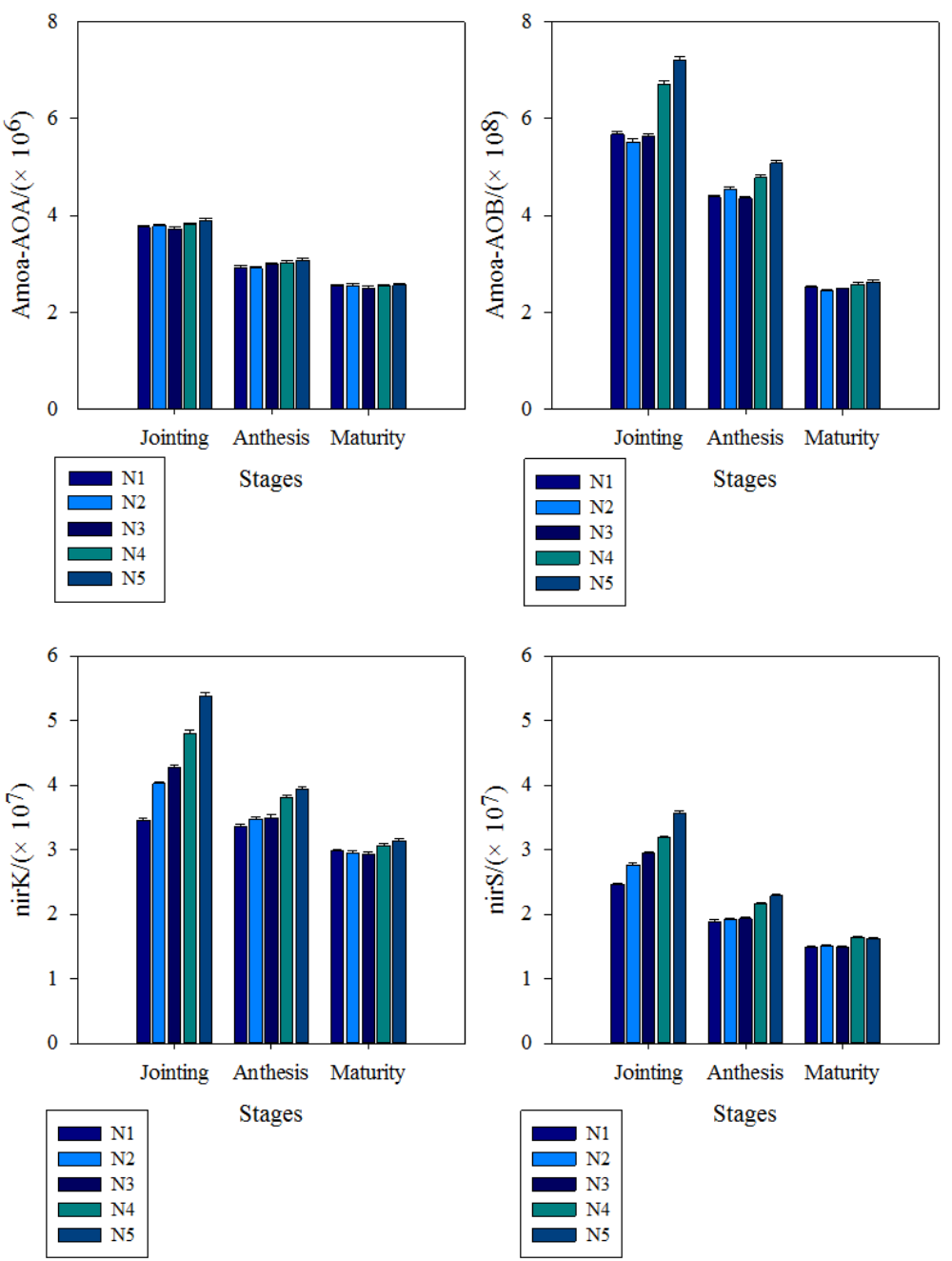

Figure 6

The effects of split nitrogen fertilizer on the abundance of Amoa-AOA: ammonia monooxygenase gene in AOA populations; Amoa-AOB: ammonia monooxygenase gene in $\mathrm{AOB}$ populations; nirK: Cu nitrate reductase gene; nirS: cd1 nitrate reductase gene. 



Figure 7

The effects of split nitrogen fertilizer on the soil nitrogen invertase activity.

\section{Figure 8}

The effects of split nitrogen fertilizer on the nitrate accumulation, ammonium nitrogen accumulation, soil microbial biomass $\mathrm{N}$ and $\mathrm{C}$.

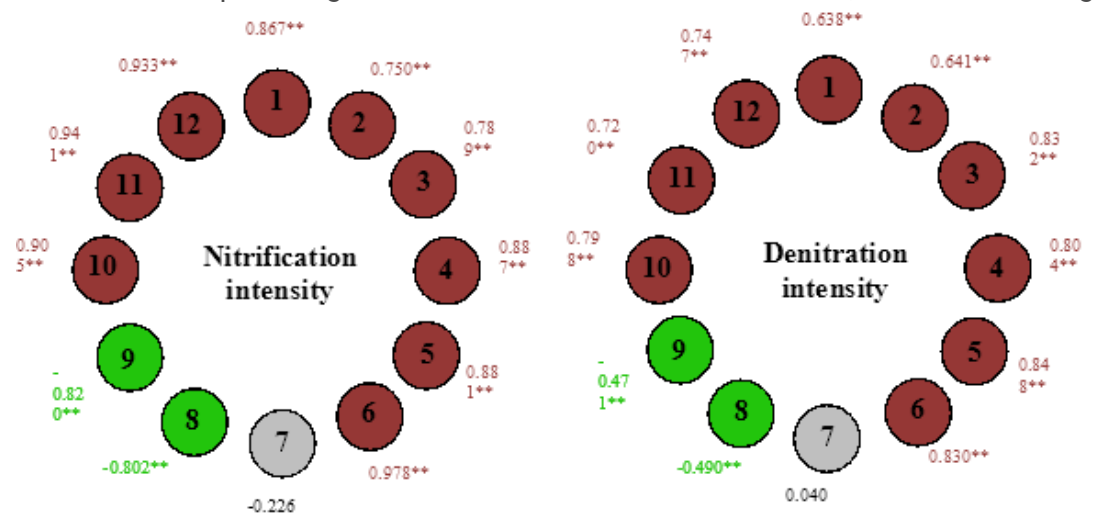

Figure 9

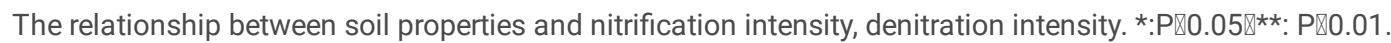



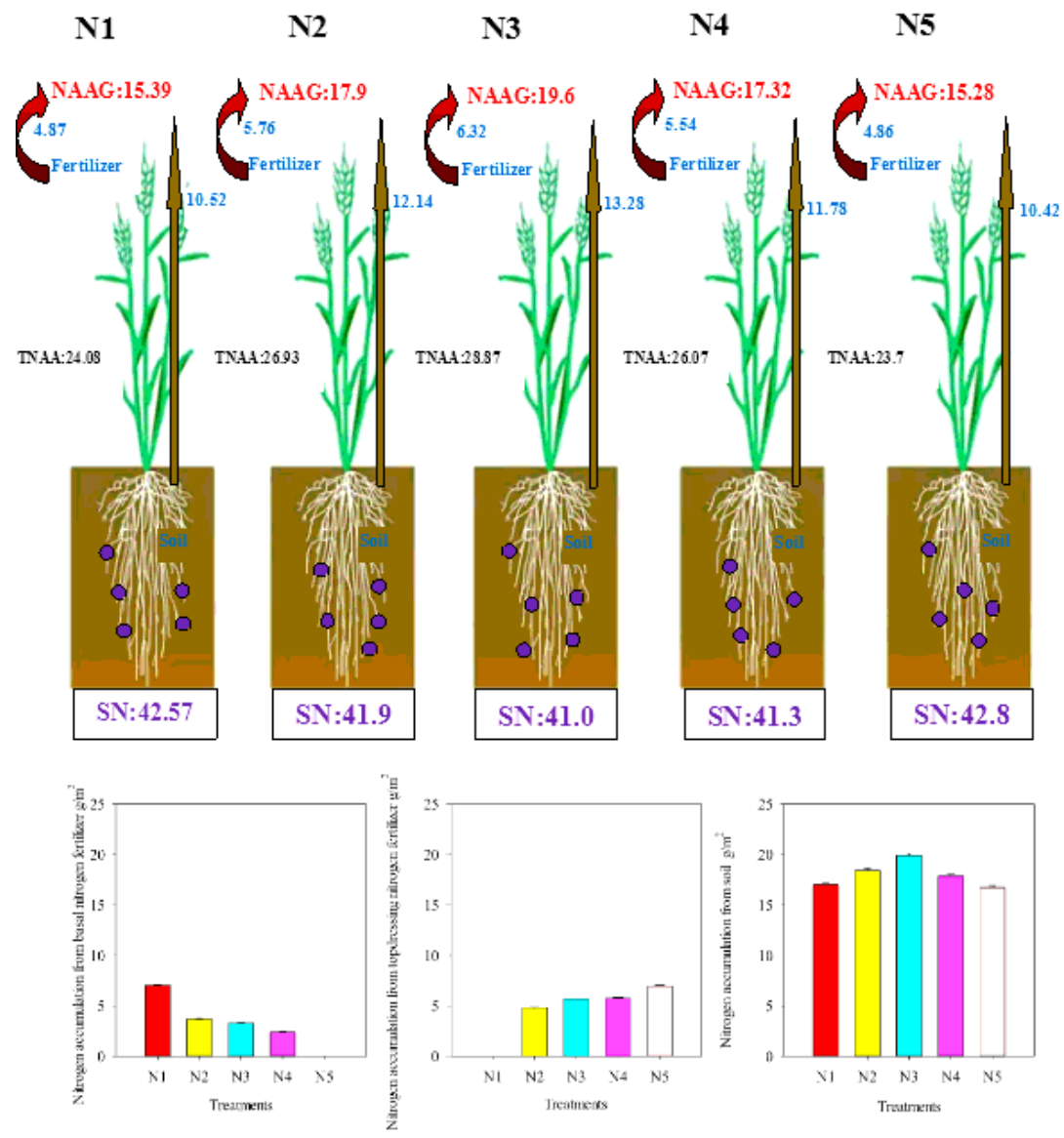

Figure 10

Effect of split nitrogen fertilizer on the plant nitrogen accumulation form fertilizer or soil. NAAG, nitrogen accumulation amount in grains; TNAA, Total plant nitrogen accumulation amount; $\mathrm{SN}$, soil inorganic nitrogen content.

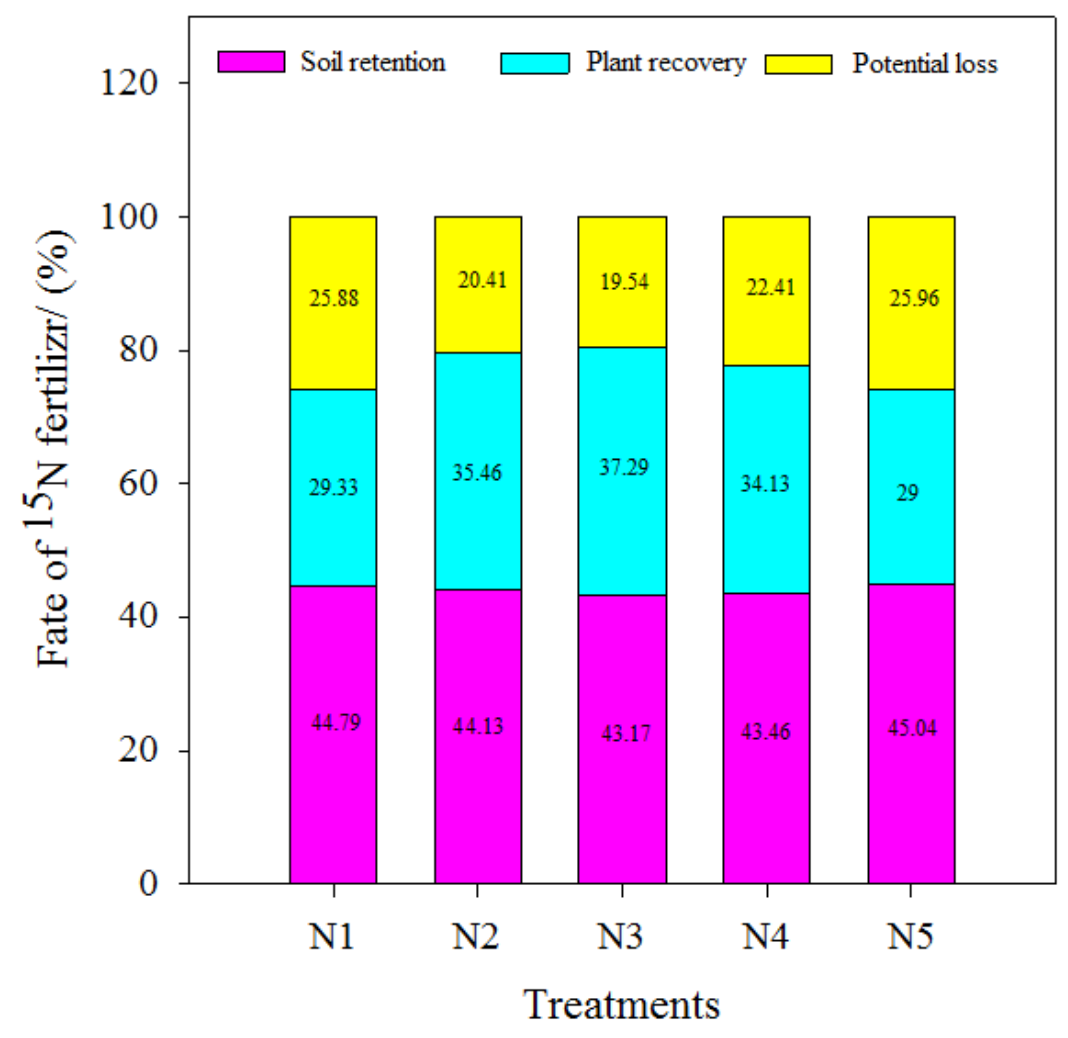

Page 20/21 
Figure 11

Effect of split nitrogen fertilizer on the fate of $15 \mathrm{~N}$ fertilizer in plant-soil system.

Page 21/21 